\title{
Research Paper \\ Study the Obstacles of Establishment of Article 38 of the Law on Civil Services Management
}

\author{
*Isa Jamshidi' ${ }^{1}$, Abd-o-llah Majidi², Nasrin Akhoondi ${ }^{3}$ \\ 1. MSc. Department of Public Management, Faculty of Management and Economics, Science and Research Branch, Islamic Azad Uni- \\ versity, Tehran, Iran. \\ 2. Assistant Professor, Faculty Member, Amin Police University, Tehran, Iran. \\ 3. Assistant Professor, Faculty Member, South Tehran Branch, Islamic Azad University, Tehran, Iran.
}

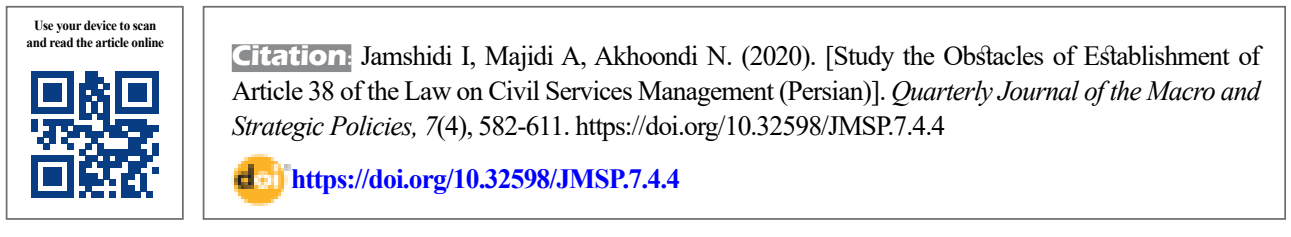

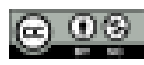

Received: 12 May 2015 Accepted: 14 May 2018 Available Online: 01 Jan 202

Key words:

E-government, Inter-organizational barriers, External barriers, Electronics city

\section{ABSTRACT}

Living in today's world with the appearance of communication and information technology caused the development of competitive advantage and in the meantime the Electronic Government is the most striking example of it from which the state institutions and organizations are going to use in order to facilitate the services and obtain the customer's satisfaction.

In spite of the entire endeavor made to implement the Electronic Government in recent years, the complete establishment of it has faced many challenges and obstacles.

This survey has been done to identify the obstacles of the establishment of the Electronic Government in Tehran municipality in which after assessing the theoretical basis of survey, ten effective factors (from past researches) in different organizations have been identified and evaluated in Tehran Municipality.

Present research is semi-exploratory and without assumption.

The questionnaire designed according to ten questions of the survey and distributed among the personnel of Tehran Municipality and the examination of the model has done by SPSS and AMOS software (kolmogorov-smirnov, confirmatory factor analysis and T-Test).

The results confirm the effects of all these ten factors included: human factors, management factors, environmental, financial, social, cultural, organizational, security, technical and political factors. The results show that these 10 factors are the most important and powerful obstacles in establishment of the Electronic Government in Tehran Municipality.

\section{* Corresponding Author:}

Isa Jamshidi

Address: Department of Public Management, Faculty of Management and Economics, Science and Research Branch, Islamic Azad University, Tehran, Iran.

Tel: +98 (912) 1901488

E-mail: jamshidi.isa@gmail.com 


\section{بررسى موانع استقرار ماده ^\ قانون مديريت خدمات كثورى در سازمانهاى

\section{"عيسى جمشيدى' •، عبدالله مجيدى '، نسرين آخوندى"}

ا. كارشناسى ارشد، كروه مديريت دولتى، دانشكده مديريت و اقتصاد، دانشخاه آزاد اسلامى، واحد علوم و تحقيقات، تهران، ايران.

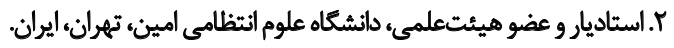

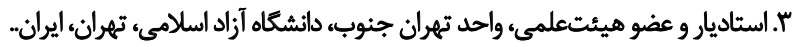

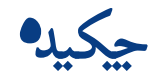

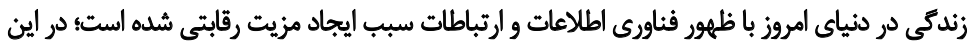

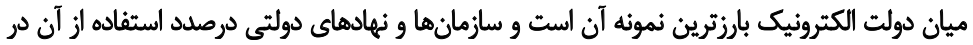

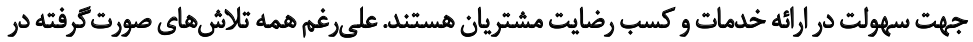

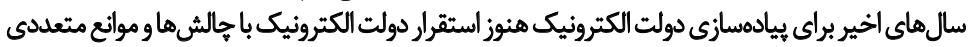

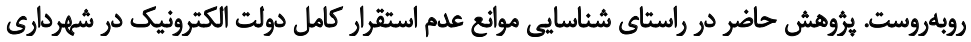

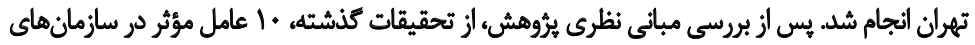

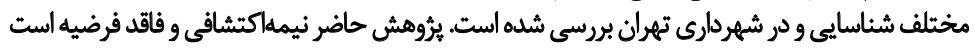

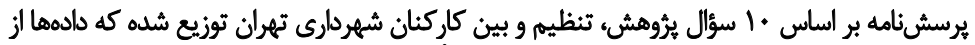

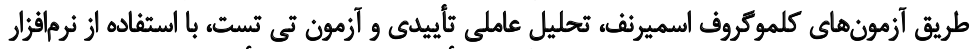

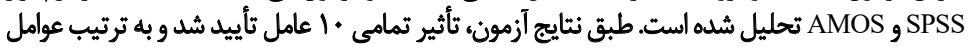

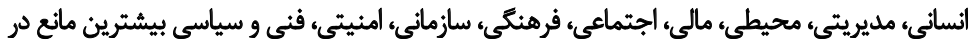

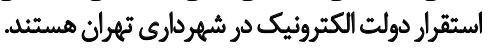

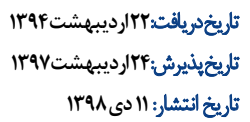

كليدوارهها:

دولت الكترونيك،

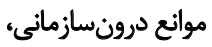
موائع برونسازماني، دروني، شهر الكترونيك بروني

* *ويسنده مسئول:

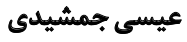
تشانى: تهر انه دانشكاه آزاد اسلامي، واحد علوم و تحقيقات، دانشكده مديريت و اقتصاد، كروه مديريت دولتي. تلفن: بست الكترونيكى: jamshidi.isa@gmail.com 


\section{dalo}

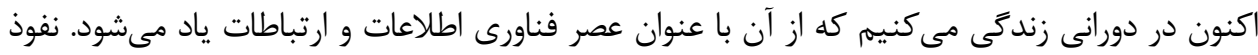

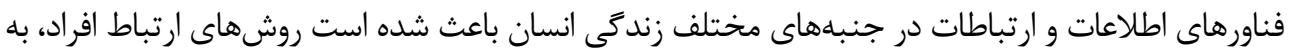

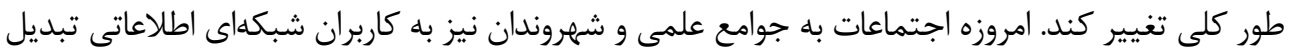

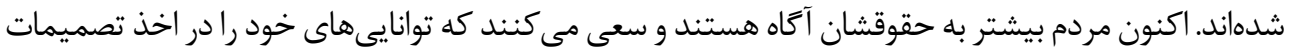

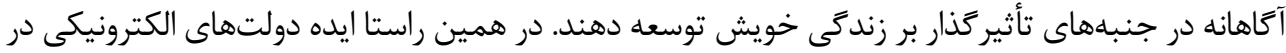

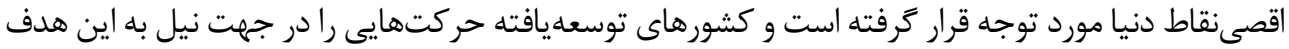

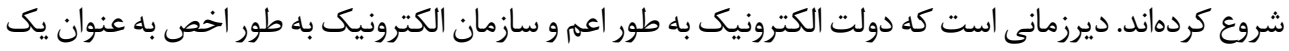

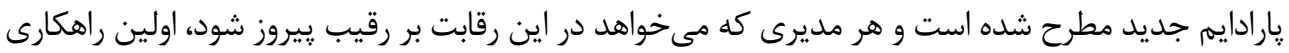

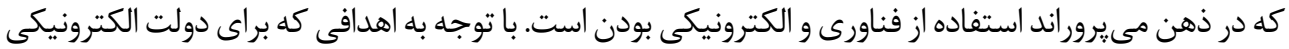

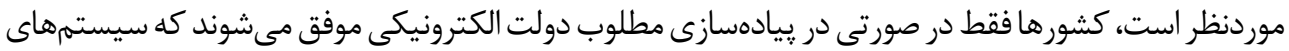

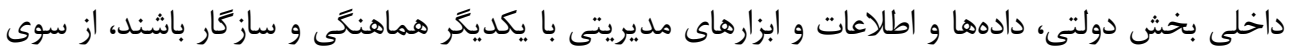

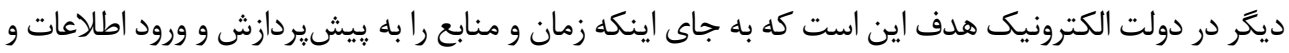

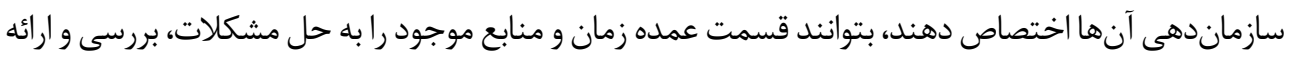

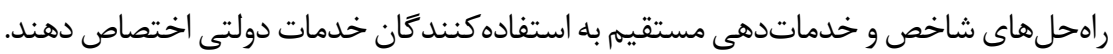

\section{ا ـ ادبيات موضوع}

از ضروريات عصر اطلاعات و ارتباطات، استقرار دولت الكترونيك براى تحقق مردمسالارى و تسهيل در امور

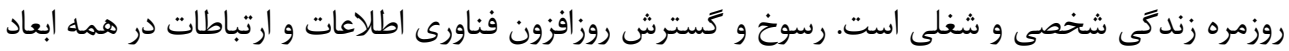

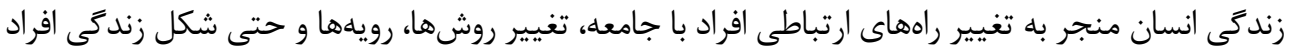

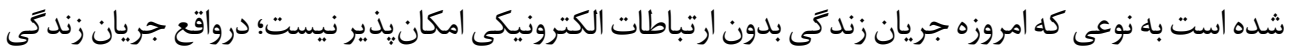

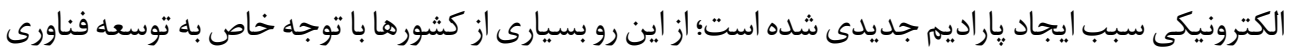

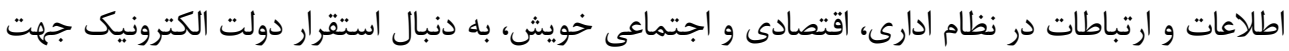

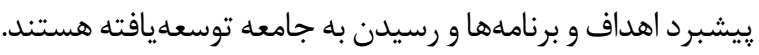

دولت الكترونيك لازمه حكومت بر جامعه اطلاعاتى است. مديريت آن نياز به خلق دولت الكترونيك مقتدر و

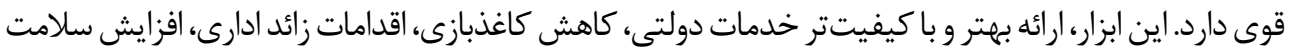

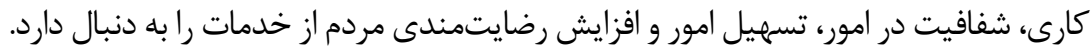
شاخص توسعه دولت الكترونيك كشورها در سه زيرشاخه خدمات آنلاين، زيرساخت ارتباطى و سرمايه انسانى

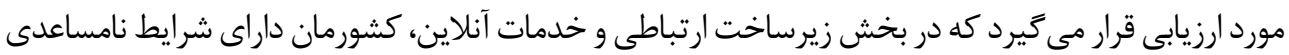

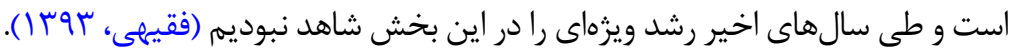


رشد شاخص خدمات برخط ايران VV/ • درصد، شاخص زيرساختى ارتباطى 9 ٪/ • درصد و شاخص سرمايه

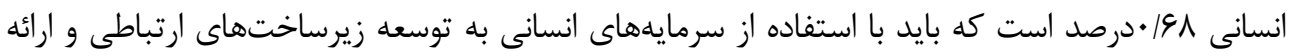

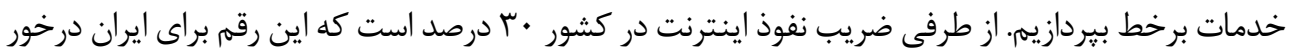

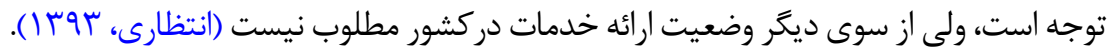
وضعيت ارائه خدمات به صورت الكترونيكى در سطح مطلوبى قرار ندارد و اين درحالى است كه برابر قانون برنامه ينجم توسعه، بايد تمامى خدمات به صورت صددرصد صد الكترونيكى ارائه شود. بزرتى

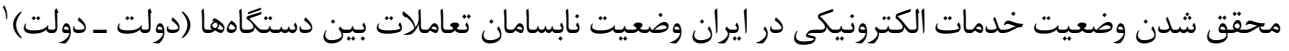

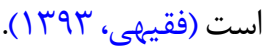

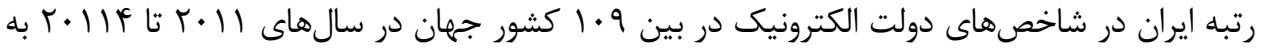

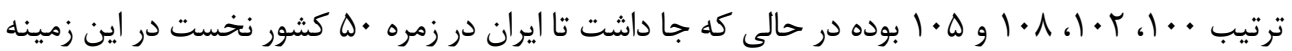

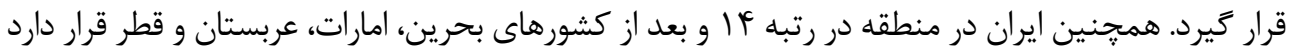

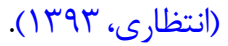

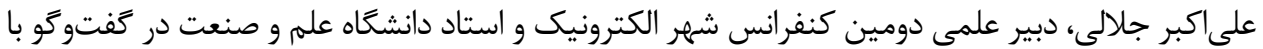

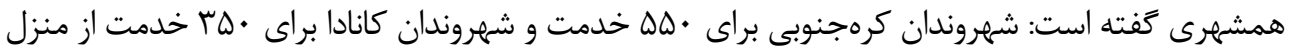

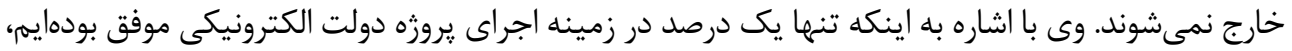

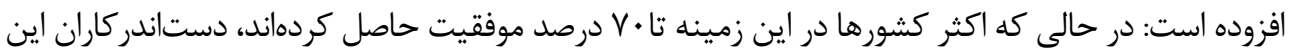

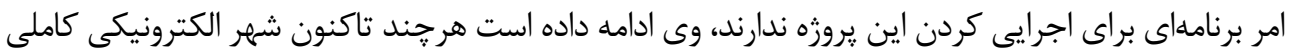

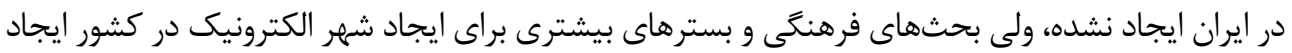

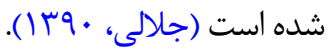

استقرار دولت الكترونيك براى نخستينبار در برنامه جهارم توسعه مطرح و گنججانده شد و اقداماتى زيادى

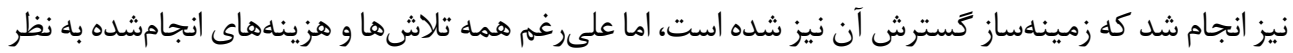

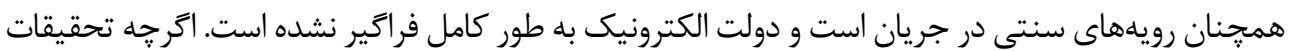

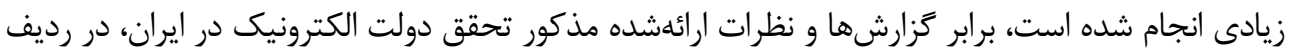
كشورهاى بسيار ضعيف قرار دارد.

\section{ت}

محيطهاى دولتى و نيمهدولتى و سازمانهايى كه بيشترين ارتباط را با اربابرجوع دارند و مسئول ارائه

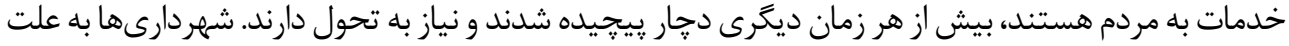

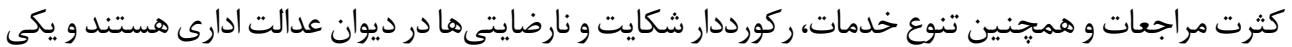


از دلايل آن عدم ياسخ گويى، شفافيت و ارائه خدمات مطلوب است. استقرار دولت الكترونيك مىتواند بخش إنش

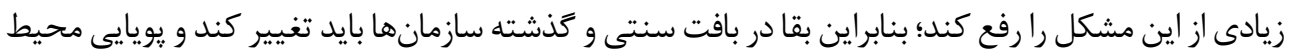

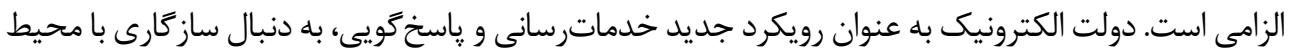

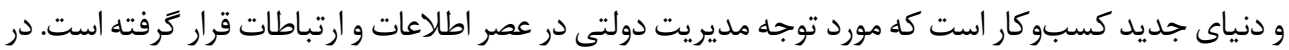

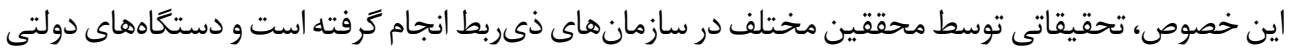

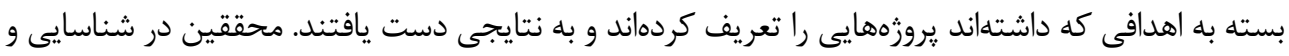

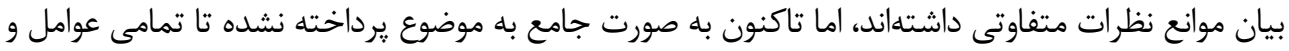

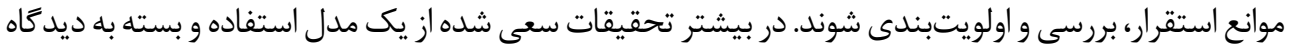

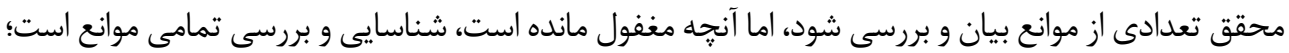

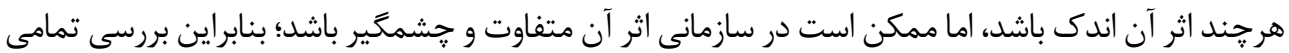

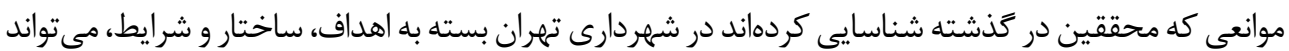

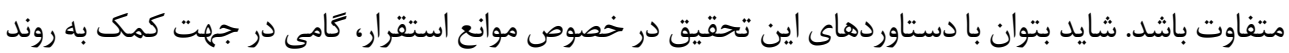

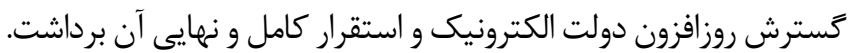

استفاده از فناورى اطلاعات و ارتباطات در حوزه داد و ستد اطلاعات و دادهها مفهوم جديدى جون دوران

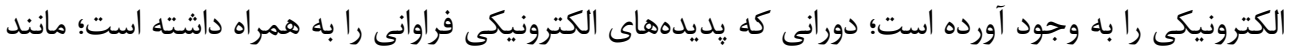

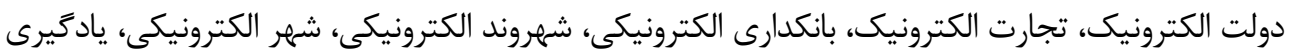
الكترونيكى و درمجموع زندكى الكترونيكى.

دولت الكترونيكى نيز يكى از اطلاعاتى است كه نتيجه كاربرد فناورى اطلاعاتى و ارتباطى در دولت است؛ به

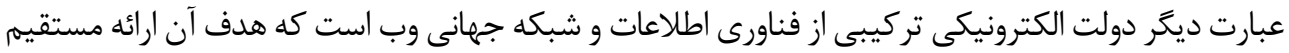

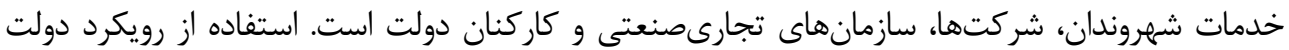

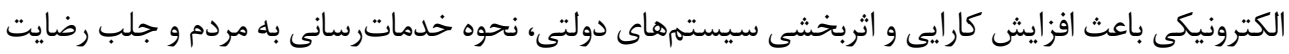

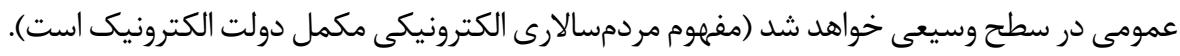

دولت الكترونيك به عنوان مفهومى جديد در عرصه حكومتدارى و فرصتهايى كه براى دولتمردان و

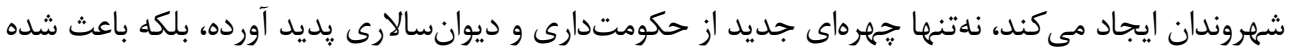

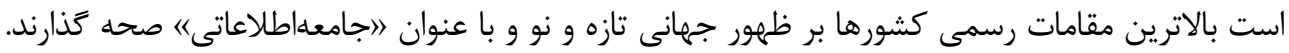

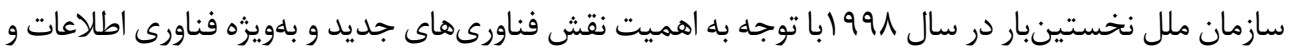

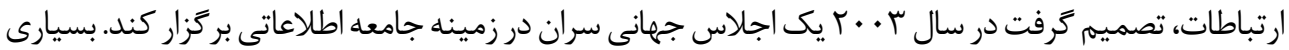

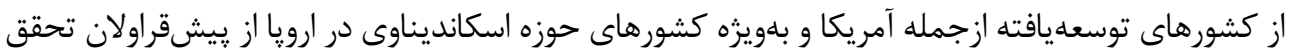

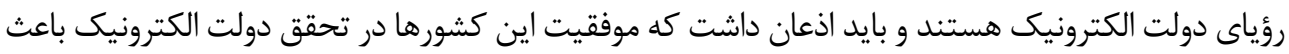

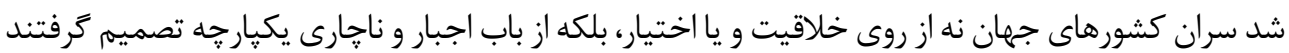

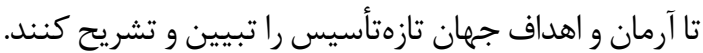


دولت الكترونيك برخلاف رويكردى كه در بسيارى از كشورهاى در حال توسعه و بهويزه خاورميانه مشاهده

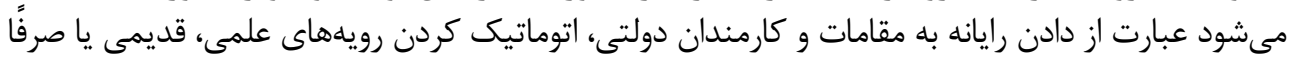

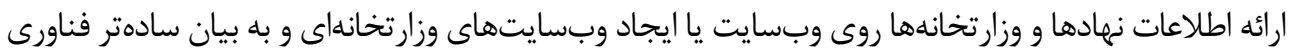

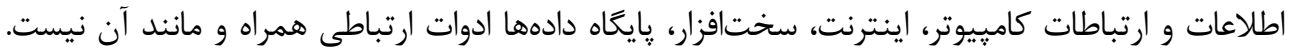

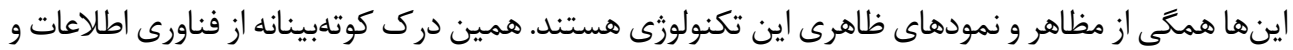

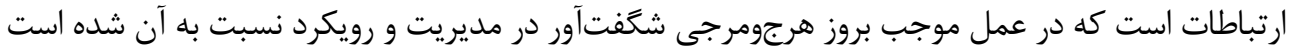

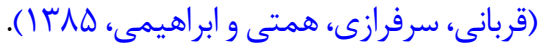

دولت الكترونيك عبارت است از استفاده از فناورىهاى اطلاعاتى و ارتباطى براى متحول كردن دولت و فرايند

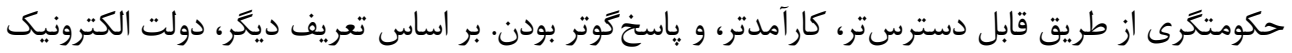

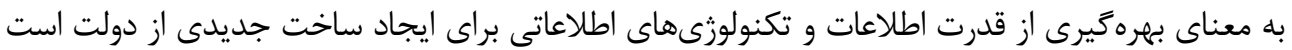

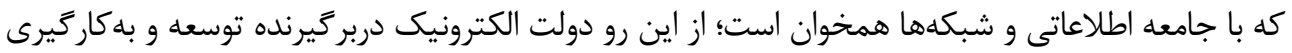

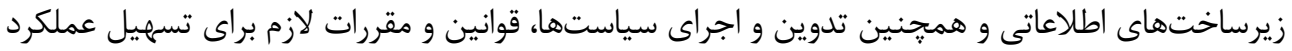

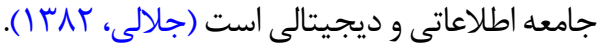

دولت الكترونيك استفاده از فناورىهاى اطلاعاتى و ارتباطى به منظور ارائه خدمات دولتى، به صورت بهنغَام و

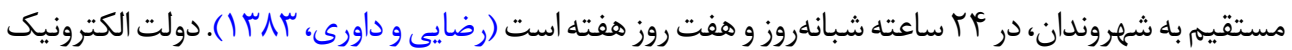

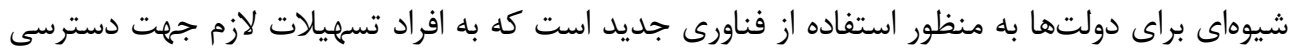

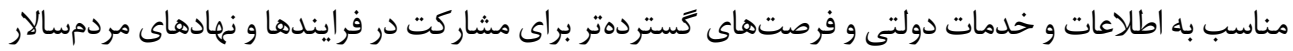

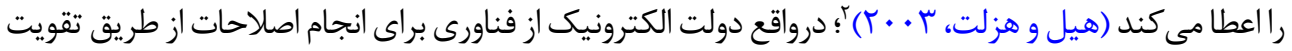

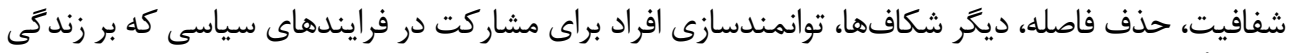

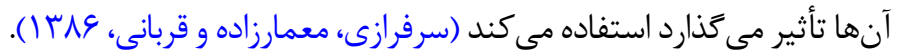

I-Y. ابعاد دولت الكتروئيكى

\section{I-Y-I. دولت _ شهروند}

اين نوع خدمت بر 》اتوانايى دولت و شهروند براى برقرار كردن ارتباط اطلاعاتى از راه الكترونيكى و كارا《ه

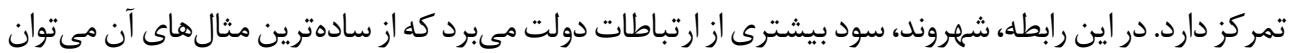

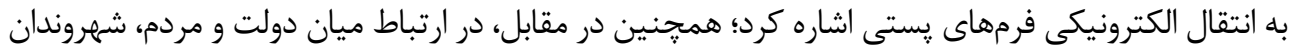

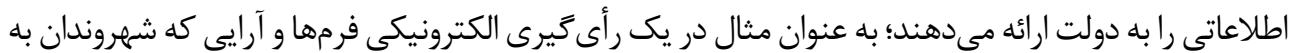

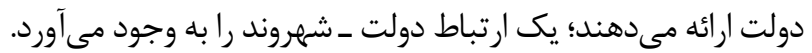

2. Hill \& Hezlett

3. Government to Citizens 


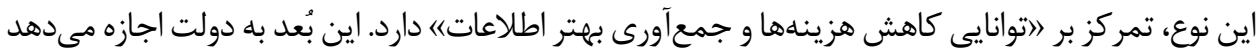

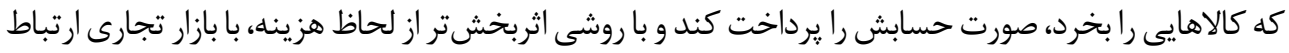

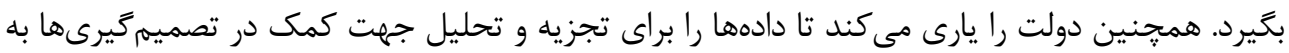

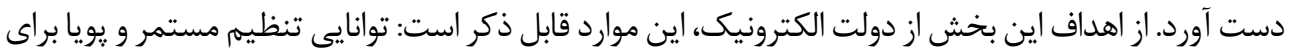

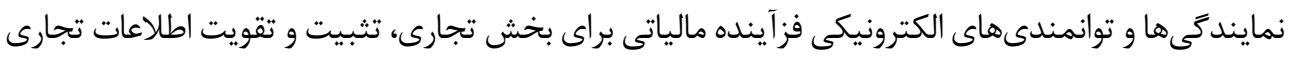

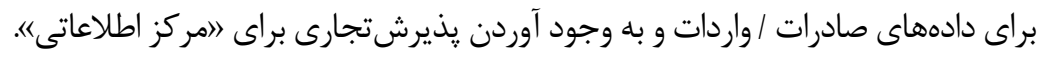

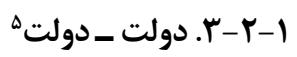

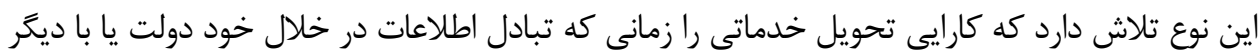

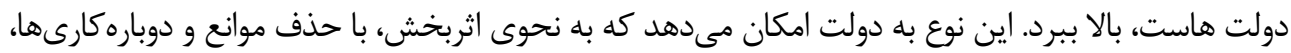

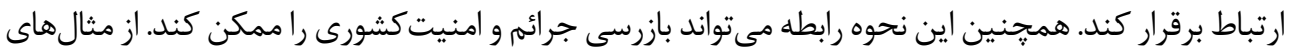

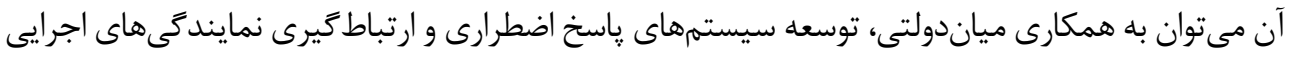
قانون، اشاره كرد.

$$
\text { \& }
$$

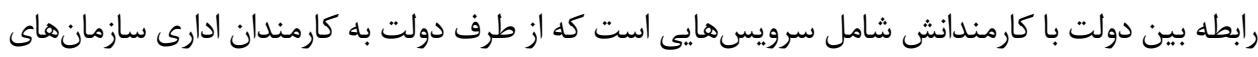

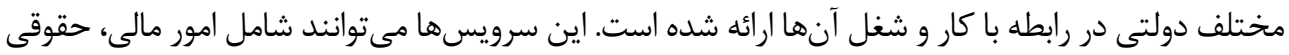

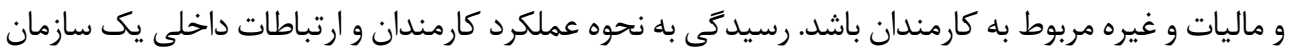

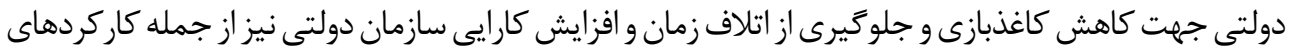
GE هست.

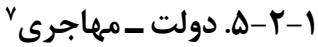

اين مؤلفه دولت الكترونيك كه بهتازكى به مدل هاى قبل افزوده شده است، در زمينه تعامل دولتها بها با كسانى

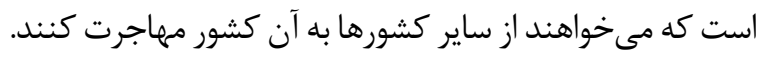

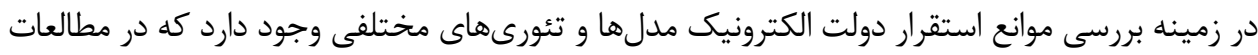

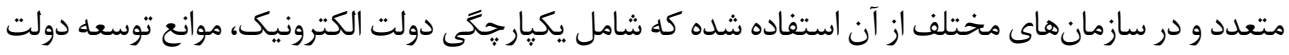

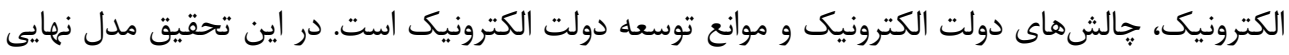
4. Government to Businesses (GB)
5. Government to Governments (GG)
6. Government to Employees (GE)
7. Government to Foreigners (GF) 
جدول ا. مدل هاى تحقيق

\begin{tabular}{|c|c|c|c|c|}
\hline مؤلفهها & موضوع مطالعه & سال تحقيق & نويسنده & رديف \\
\hline موانع فناورى، ساختارى، حقوقى و فرهنكى اجتماعى & الكيارجكي دولت & IYM & (يعقوبى، (IrM) & 1 \\
\hline استراتثرى، تكنولوزى، سياستهسازمانى & إلشترونيك دولت & $r \cdot a$ & لام & $r$ \\
\hline موانع اجتماعى، تكنولوزى، مديريتى، موانع مربوط به & جالش الكترونيك دولت & $r \cdot \Delta$ & وسيلاكس & $r$ \\
\hline فنيء سازماني، قانوني، سياسيى & الشتهاي دولت & $r \cdots \Delta$ & رانى & $p$ \\
\hline 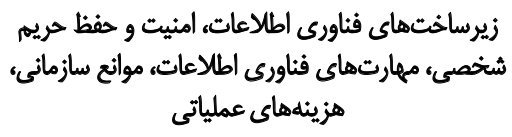 & موانع تونسه دولت & $r+\infty$ & (إبراهيمى و ايراثنى، & $\Delta$ \\
\hline فرهنكه سياست، تكنولوزى & 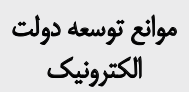 & $|r q|$ & 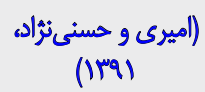 & 8 \\
\hline
\end{tabular}

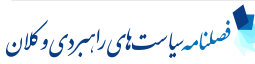

برگرفته از اين مدل ها و با تأكيد بر تمامى موانع شناسايىشده در تحقيقات كذشته بوده است تا كوجكترين و

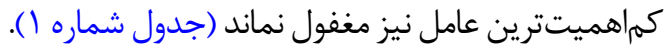

1

هدف اصلى تحقيق بررسى و اولويتبندى موانع مؤثر در استقرار دولت الكترونيك در سازمانهاى دولتى بوده

بررسى و اولويتبندى عوامل مديريتى مانع استقرار دولت الكترونيك در شهردارى تهران؛ بررسى و اولويتبندى

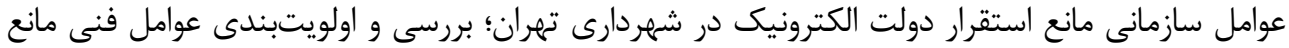

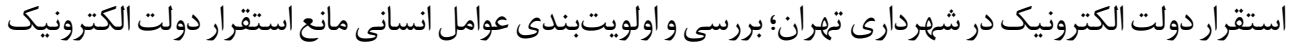

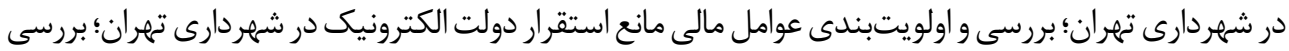

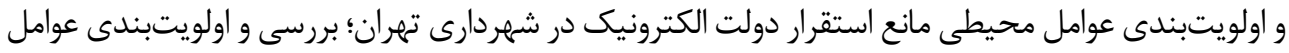

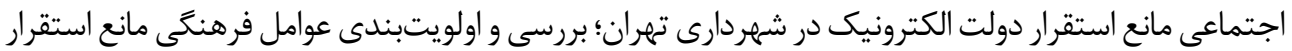




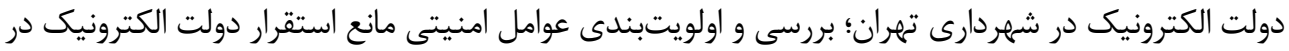

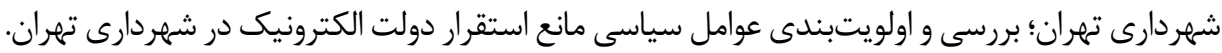

1- 1-2. سوُال اصلى تحقيث

موانع استقرار دولت الكترونيك در شهردارى تهران كداماند؟

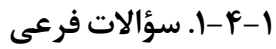

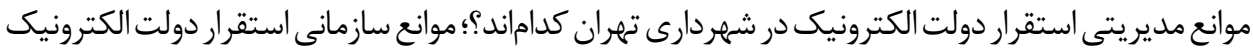

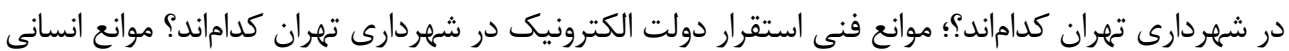

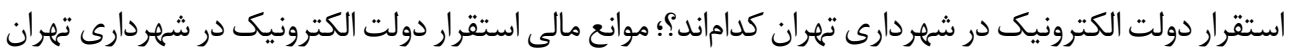

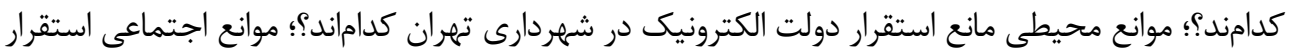

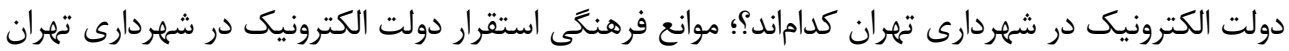

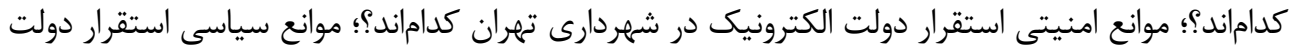

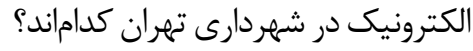

1-0. - موانع اسثقرار دولت الكترونيك

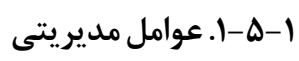

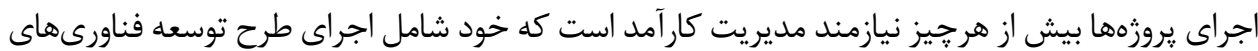

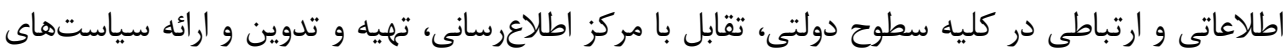

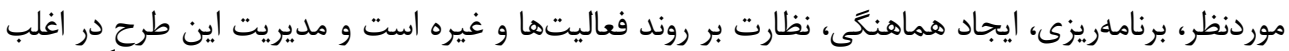

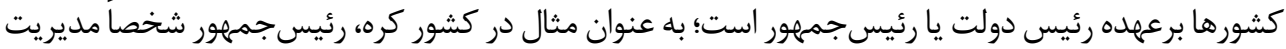

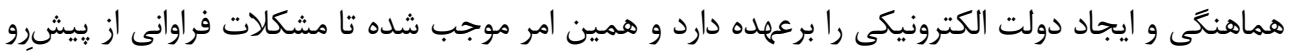

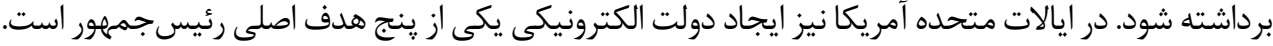

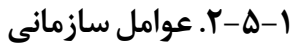

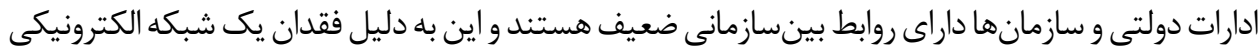

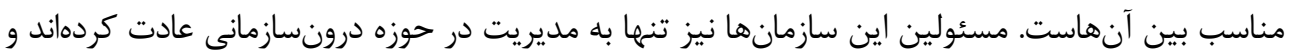

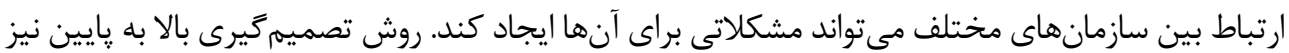

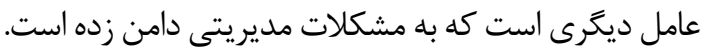

در يك نظام دولتى الكترونيك، موانع و حصارهاى بينسازمانى برداشته شده و دولت از يك نظام بسته و 
محتاط به يك نظام باز كه در آن نوآورى حرف اول را مىزند تبديل شده است. يكى از راههاى مؤثر مىتواند

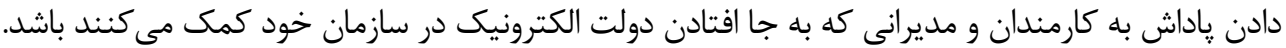

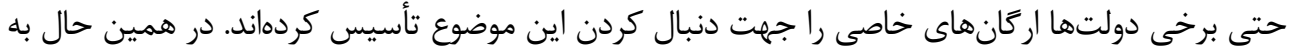

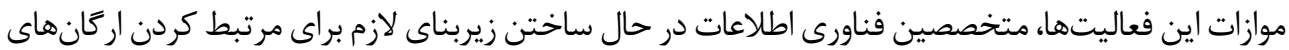
مختلف به يكديكر هستند.

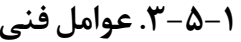

عوامل فنى، عواملى از قبيل نرمافزار و سختافزار مناسب، مطابقت سيستهم با كاربران، زيرساختهاى

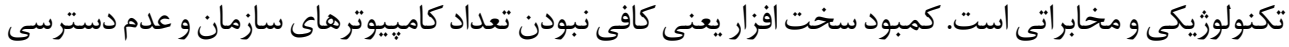

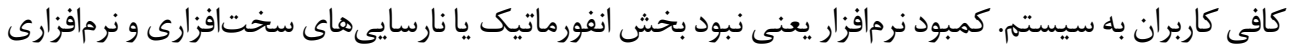

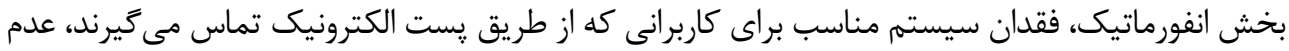

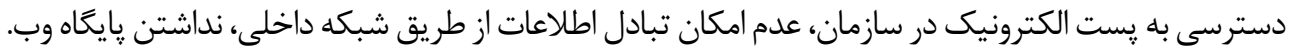

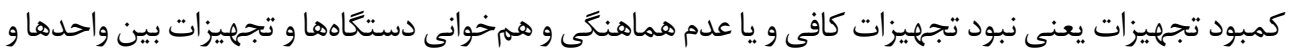

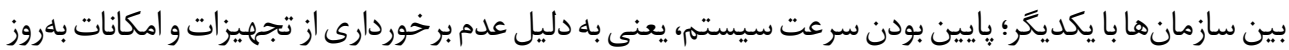

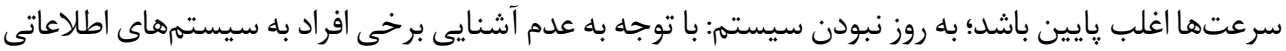

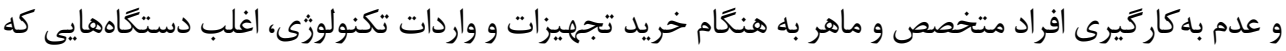

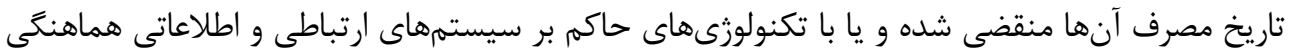

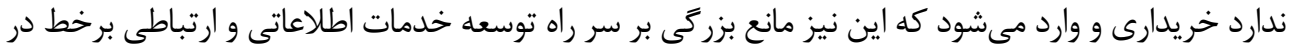
سازمان هاى دولتى است.

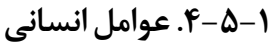

در حال حاضر در جوامع ييشرفتهاى مانند ايالات متحده، كمبودى از لحاظ منابع تكنولوزيك احساس

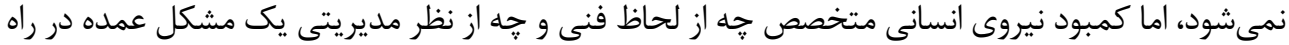

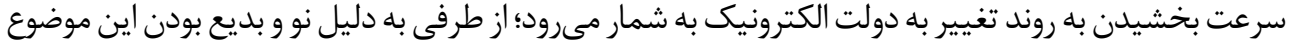

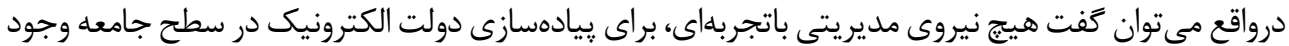

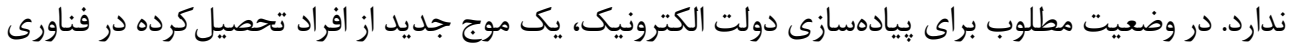

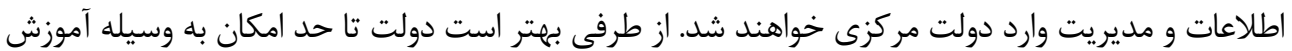

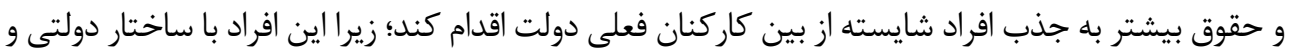

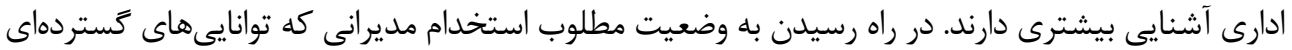

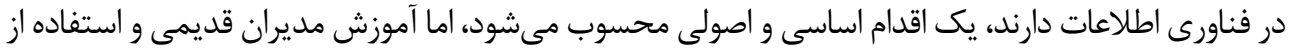

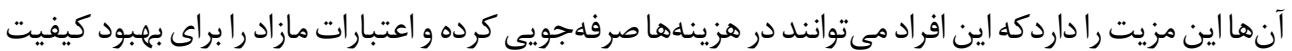

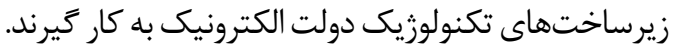




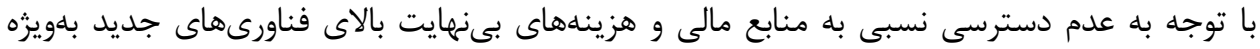

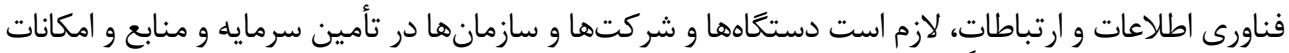

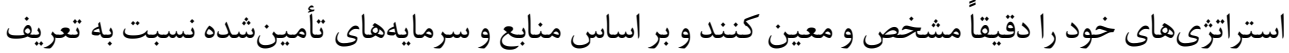

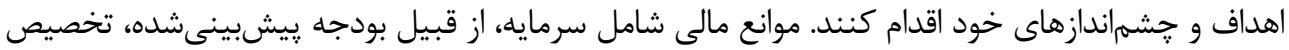

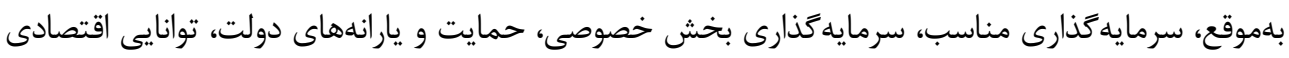

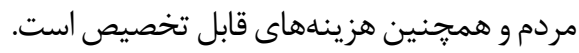

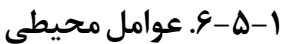

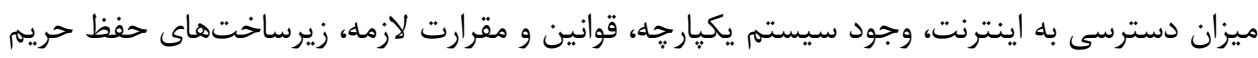

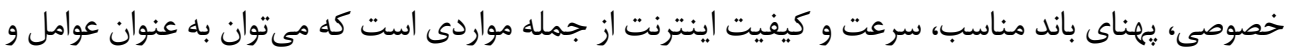

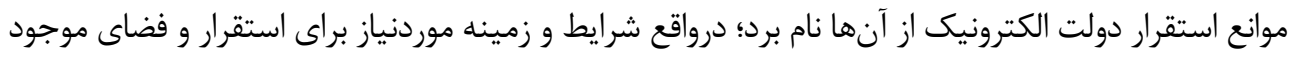

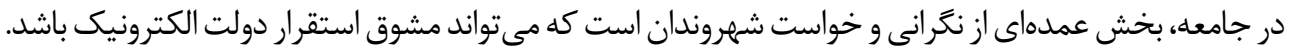

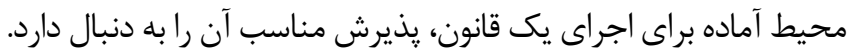

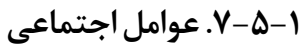

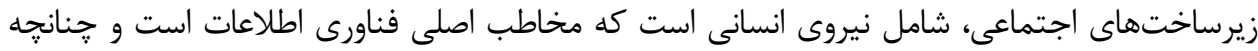

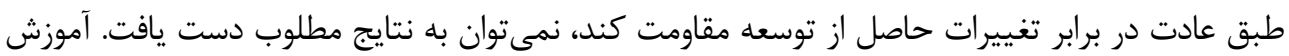

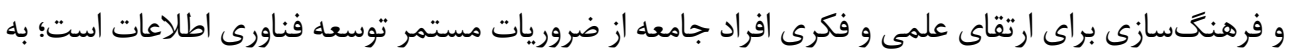

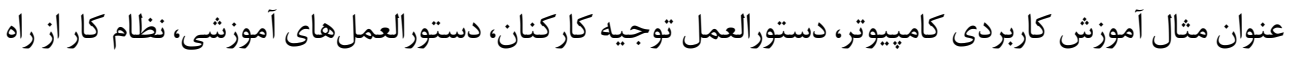

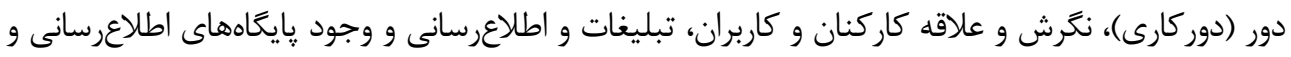

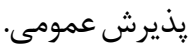

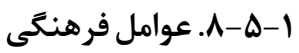

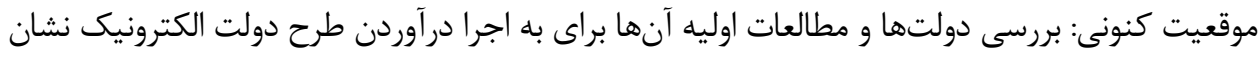

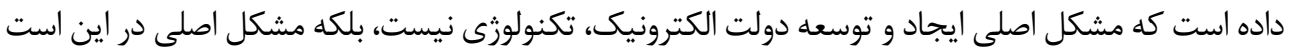

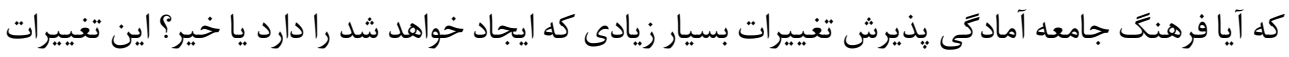

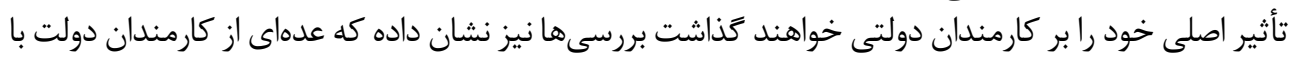

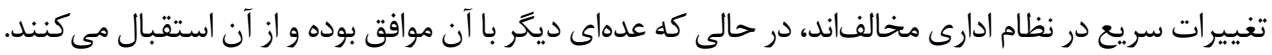

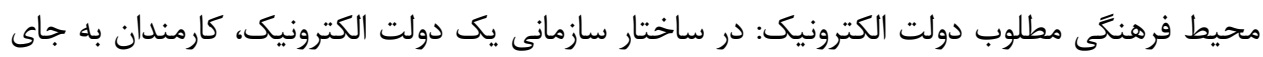

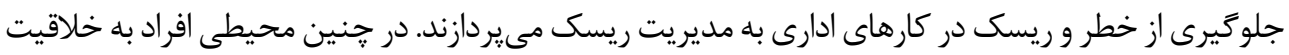




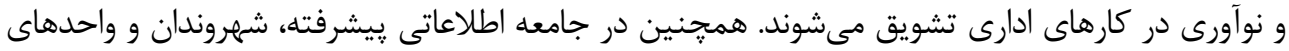

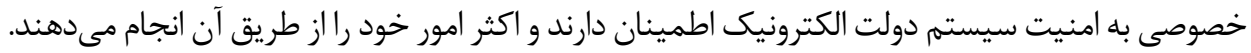

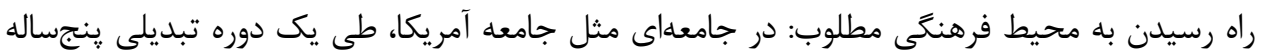

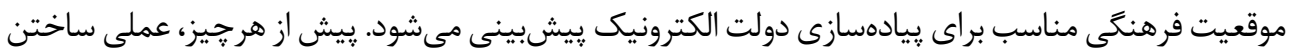

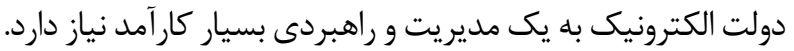

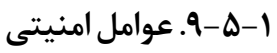

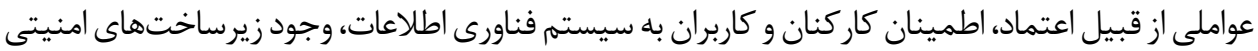

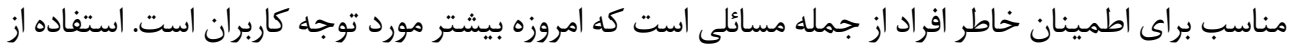

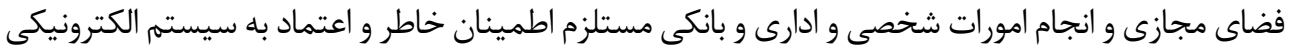

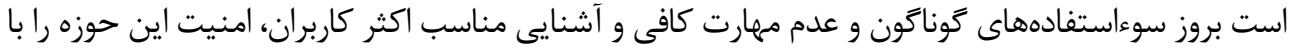

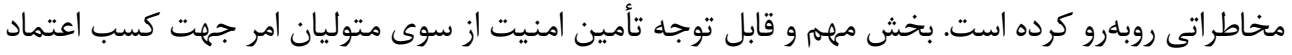
كاربران در استفاده از دولت الكترونيك است

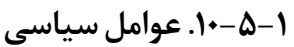

در اين زمينه عواملى از قبيل نكرشهاى سياسى در خصوص استفاده از فناورى اطلاعات و ارتباطات،

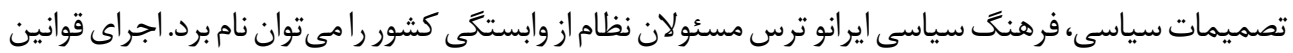

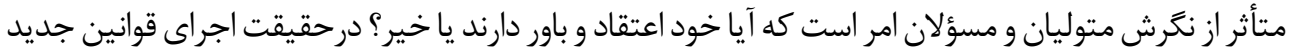

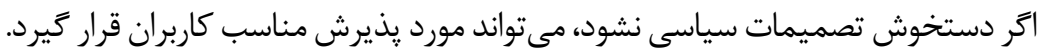

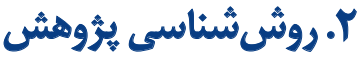

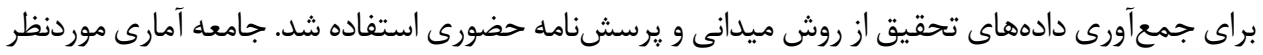

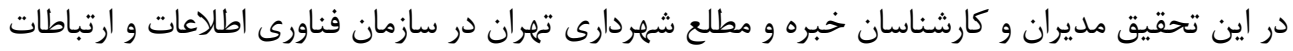

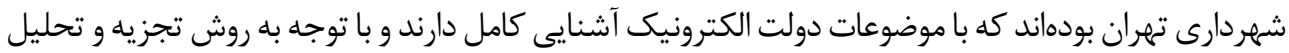

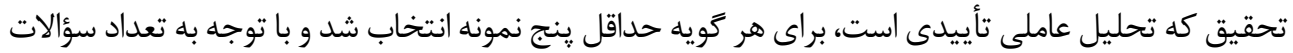

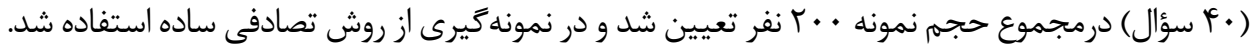

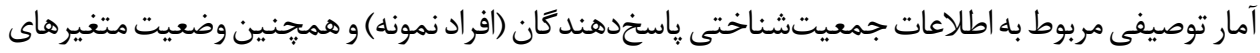

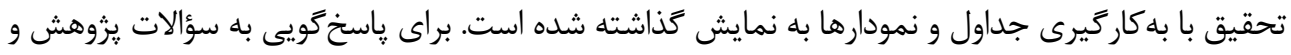

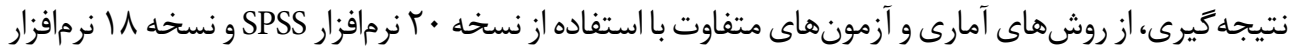

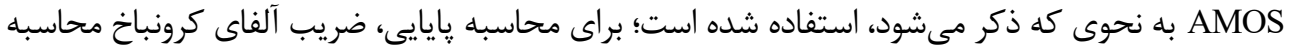

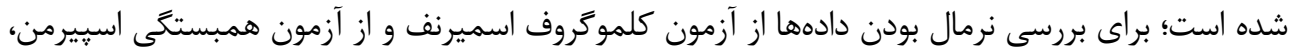


تحليل عاملى تأييدى، آزمون تى تست و ضريب همبستگى جندگًانه براى آزمون فرضيات استفاده شده است.

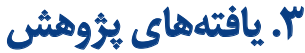

مدل اندازهيرى نشاندهنده بارهاى عاملى متغيرهاى مشاهدهشده (عامل) براى هر متغير مكنون است.

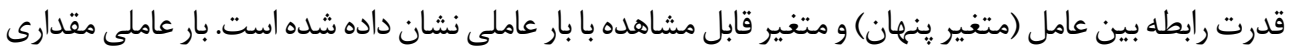

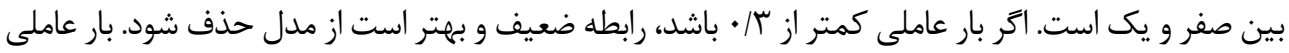

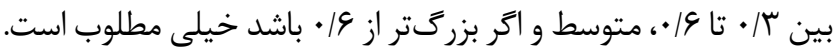

در تحليل عاملى تأييدى، توجه به برازش مدل نيز مهرم است. شاخصهاى برازش رايج در مدل هاى اندازهذيرى

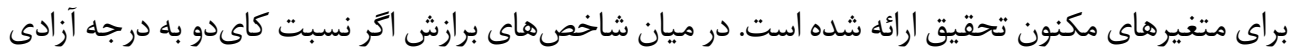

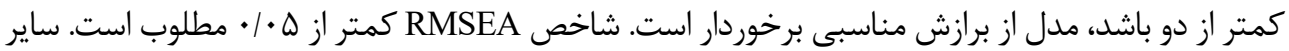

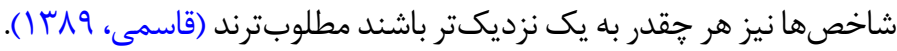

\section{"-1- تحليل عاملى ثأييدى مثتير عوامل مديريتى}

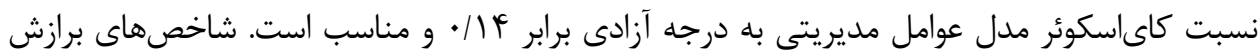

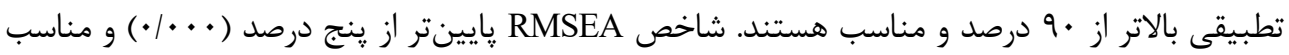

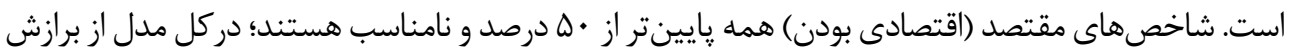

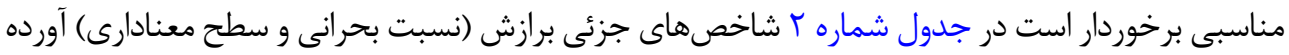
شده است.

در جدول شماره ऍ رابطه تمامى عامل ها با متغير مكنون تأييد شد (سطح معنادارى مربوط به كليه سؤالات

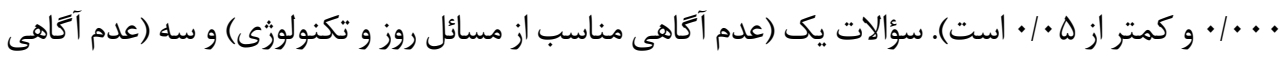

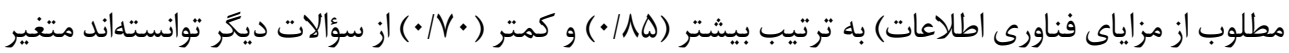
عوامل مديريتى را اندازهخيرى كنند.

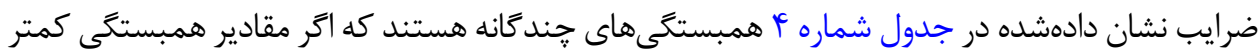

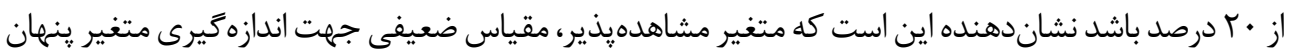

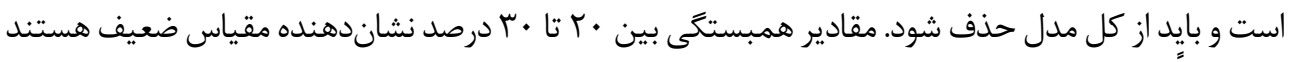

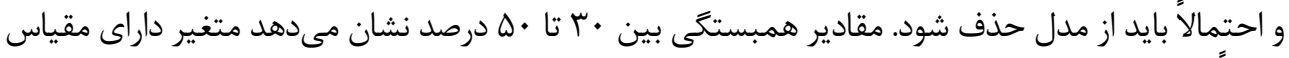

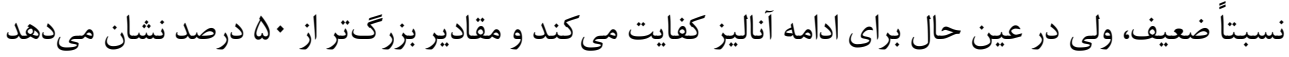

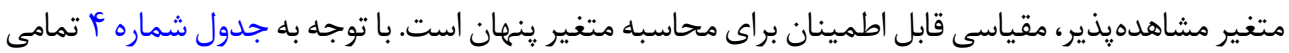

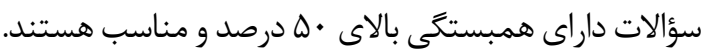


جدول r. شاخص هاى برازش مدل

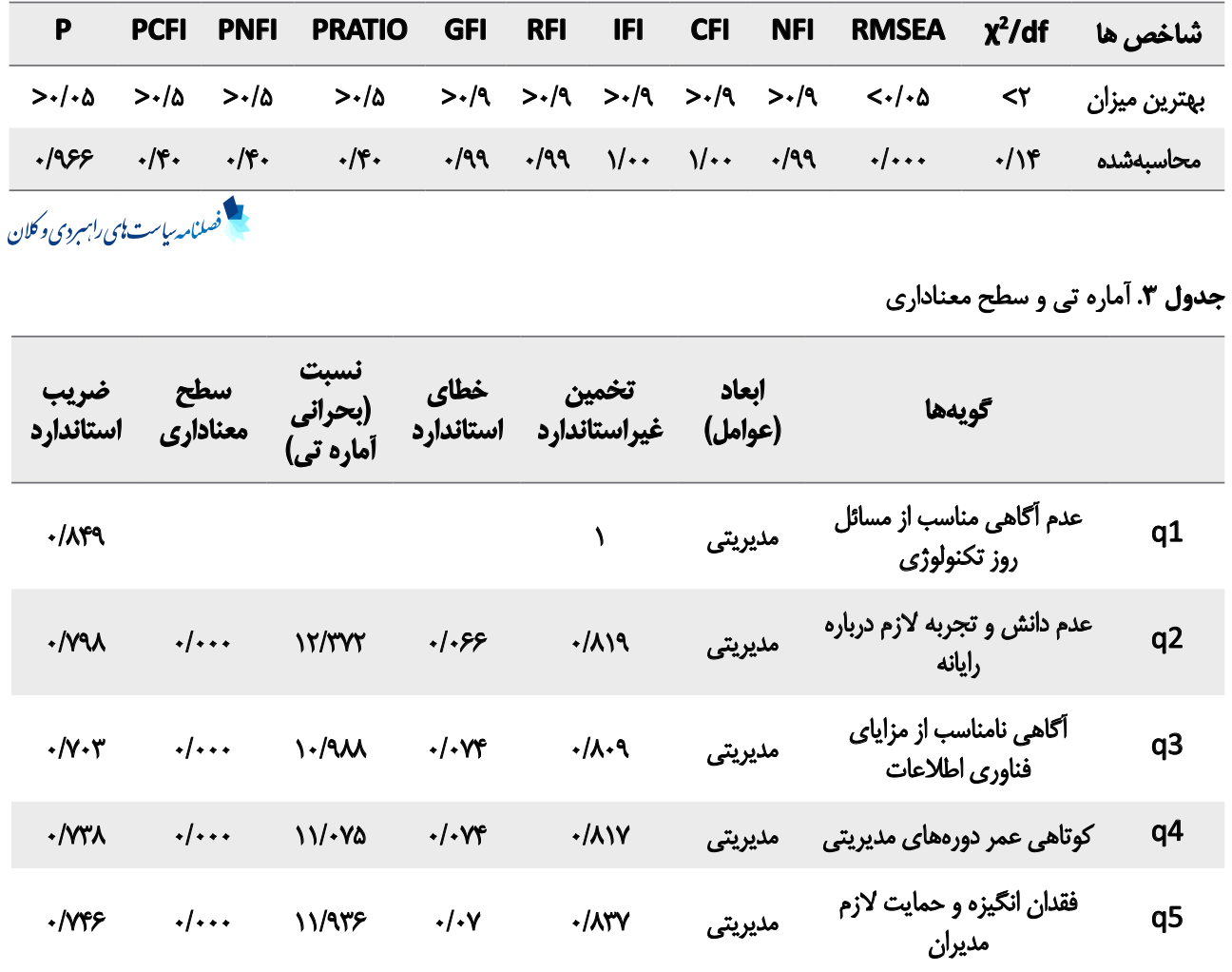

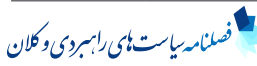

جدول f. مريع ضريب همبستكى هاى جيد كانه

\begin{tabular}{|c|c|}
\hline Estimate & كويهها \\
\hline - IAOV & q5 \\
\hline - IAPA & q4 \\
\hline - /pqp & q3 \\
\hline - Ietr & $q 2$ \\
\hline$\cdot M$ & $q 1$ \\
\hline
\end{tabular}




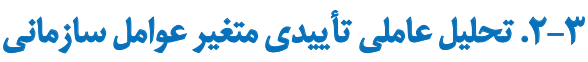

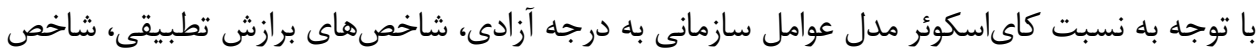
RMSEA

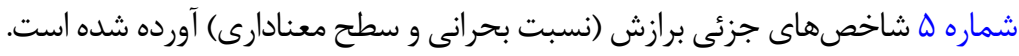

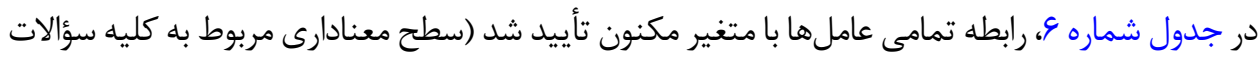

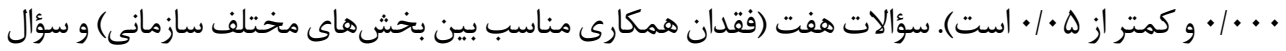

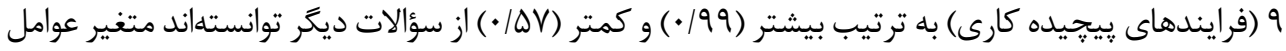
سازمانى را اندازهخيرى كنيند.

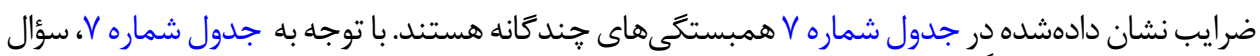

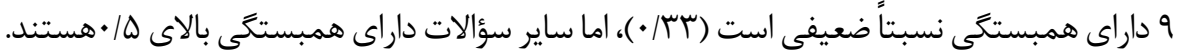

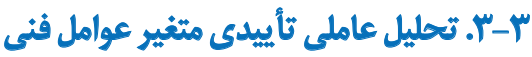
با توجه به نسبت كاىاسكوئر مدل عوامل سازمانى به درجه آزادى، شاخصهاى برازش تطبيقى، شاخص

جدول ه. شاخص هاى برازش مدل

\begin{tabular}{|c|c|c|c|c|c|c|c|c|c|c|c|}
\hline $\mathbf{P}$ & PCFI & PNFI & PRATIO & GFI & RFI & IFI & CFI & NFI & RMSEA & $x^{2} / d f$ & شُاخص ها \\
\hline$>.1 \cdot 0$ & $>\cdot 1 \Delta$ & $>. / \Delta$ & $>+10$ & $>. / 9$ & $>\cdot / 9$ & $>\cdot 19$ & $>\cdot / 9$ & $>+/ 9$ & $<+1+\Delta$ & $<r$ & بهترين ميزان \\
\hline . /raf & +118 &.$/ 18$ & .118 & .199 & .199 & $1 / .$. & $V /$. &.$/ 99$ & $\%$ & $\cdot M r$ & محاسبرأشلهد \\
\hline
\end{tabular}

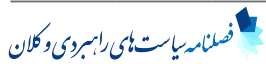

جدول \&. آماره تى و سطح معنادارى

\begin{tabular}{|c|c|c|c|c|c|c|c|}
\hline 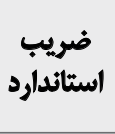 & معادرارى & 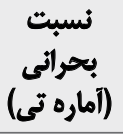 & أستاندارو & غير استانيدارد & (عوامل) & كويهها & \\
\hline - Mar & & & & 1 & سازمانى & (فقدان دستور العمل هاى شفاف) & $q 6$ \\
\hline.$/ 48$ & $\%$ & iflmes & .1 .94 & $1 /$ Tre & سازمانى & 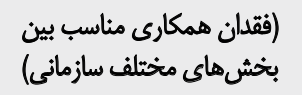 & q7 \\
\hline$+11 \cdot 9$ & .10 & Ir/AVA & $+1+9$ & $1 / 18$ & سازمانى & (بلند بودن هرم سازمانى) & q8 \\
\hline$+/ \Delta V \Delta$ & $\%$ & NoIf & $1 \cdot 18$ & $\cdot M^{\mu}$ & سازمانى & (فرايندهاى ييجيديده كارى) & q9 \\
\hline
\end{tabular}

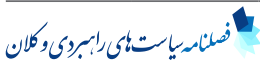


جدول V. مربع ضريب همبستكى هاى جيندكانه

\begin{tabular}{|c|c|}
\hline Estimate & كويهها \\
\hline.$/ M$ & q9 \\
\hline .180 & q8 \\
\hline .1967 & q7 \\
\hline .1819 & $q 6$ \\
\hline
\end{tabular}

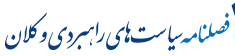

جدول A. شاخص هاى برازش هدل

\begin{tabular}{|c|c|c|c|c|c|c|c|c|c|c|c|}
\hline $\mathbf{P}$ & PCFI & PNFI & PRATIO & GFI & RFI & IFI & CFI & NFI & RMSEA & $\chi^{2} / \mathrm{df}$ & شاخص ها \\
\hline$>+1.0$ & $>.10$ & $>+10$ & $>+10$ & $>+19$ & $>. / 9$ & $>. / 9$ & $>+19$ & $>. / 9$ & $<+/ \cdot \Delta$ & $<r$ & بهترين ميزان \\
\hline ./DFE & $+/ 18$ & .118 & $+/ 18$ &.$/ 99$ &.$/ 99$ & $y+$. & $V /$. &.$/ 99$ & $1 \ldots$ & . & محاسبهشدله \\
\hline
\end{tabular}

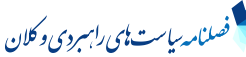

RMSEA ᄉ شاخصهاى جزئى برازش (نسبت بحرانى و سطح معنادارى) آورده شده استه

در جدول شماره 9، رابطه تمامى عاملها با متغير مكنون تأييد شد (سطح معنادارى مربوط به كليه سؤالات

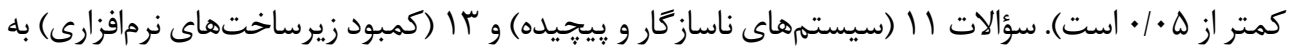

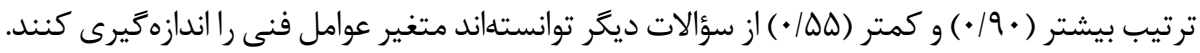

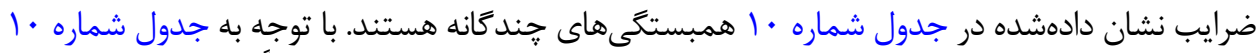

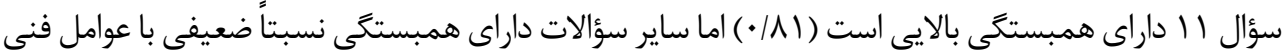

\section{ب- ب. تحليل عاملى تأييدى مثغير عوامل انسانى}

با توجه به نسبت كاىاسكوئر مدل عوامل سازمانى به درجه آزادى، شاخصهاى برازش تطبيقى، شاخص مداء RMSEA

ضرايب نشان دادهشه در جدول شماره || || همبستخى هاى جندكَانه هستند با توجه به جدول شماره || دو

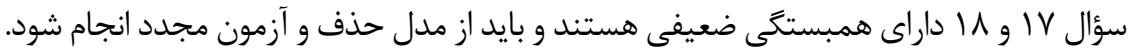


جدول 9.

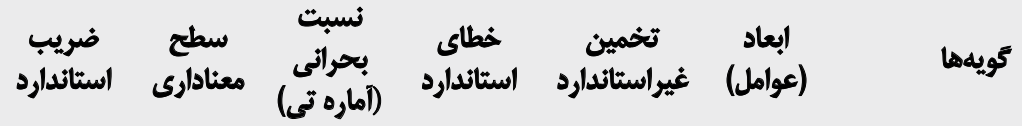

\begin{tabular}{|c|c|c|c|c|c|c|c|}
\hline .1981 & & & & 1 & فنى & (كمبودزيرساختهاى & q10 \\
\hline$\cdot / 9 \cdot T$ & $1 \ldots$ & $V / q+F$ &.$/ 19$ & $1 / \Delta \Delta \mid$ & فنى & (سيستهمهاى ناسازكار و & q11 \\
\hline - RETA & .1. & VIFoV & . & - /99V & فنى & 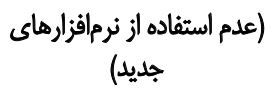 & q12 \\
\hline . late & 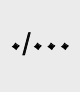 & ENPT & ./1r & - IAVA & فني & (كمبود زيرساختهائ & q13 \\
\hline
\end{tabular}

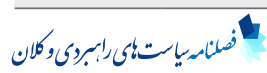

جدول •1. مربع ضريب همبستكى هاى جندكائه

\begin{tabular}{|c|c|}
\hline Estimate & كويdها \\
\hline.$/ r q u$ & q13 \\
\hline - /mqp & q12 \\
\hline$-|A| \Delta$ & q11 \\
\hline - Mtee & q10 \\
\hline
\end{tabular}

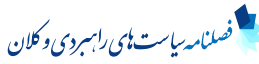

جدول ال. شاخصهاي برازش مدل

\begin{tabular}{|c|c|c|c|c|c|c|c|c|c|c|c|}
\hline $\mathbf{P}$ & PCFI & PNFI & PRATIO & GFI & RFI & IFI & CFI & NFI & RMSEA & $x^{2 / d f}$ & شاخص ها \\
\hline$>+1+\Delta$ & $>\cdot 10$ & $>-10$ & $>\cdot 10$ & $>\cdot / 9$ & $>. / 9$ & $>. / 9$ & $>+/ 9$ & $>\cdot 19$ & $<+1+\Delta$ & $<r$ & مهترين ميزان \\
\hline . &.$/ 4$ &.$/ 49$ &.$/ 4$ & .199 & .198 & $1 /$. & $\mathrm{V} /$. &.$/ 41$ & 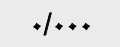 &.$/ 90$ & محاسبه شده \\
\hline
\end{tabular}

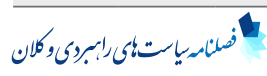




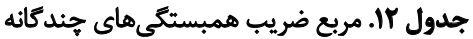

\begin{tabular}{|c|c|}
\hline Estimate & كويdها \\
\hline.$/ \mathrm{HV}$ & q18 \\
\hline.$/ 18$ & q17 \\
\hline.$/ D N C$ & q16 \\
\hline$. / 9+1$ & q15 \\
\hline.$/ r u$ & q14 \\
\hline
\end{tabular}

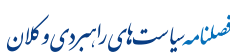

جدول سا. آماره تي و سطح معنادارى

\begin{tabular}{|c|c|c|c|c|c|c|c|}
\hline ضريب & معادارى & نسبيت & استانداري & غيراستخاندارد & 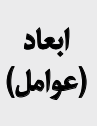 & كويهها & \\
\hline . feq & & & & 1 & أنسائي & (كمبود مهارتهاى فنى & q14 \\
\hline - NES & & & & 1 & انساني & (مقاوهت در برابر تغييي) & $q 15$ \\
\hline - AAMP & $1 \ldots$ & $1 . / F A C$ &.$/ 114$ & $1 / 19$ & أنسانى & (كمبود نيروى آموزشديده) & q16 \\
\hline
\end{tabular}

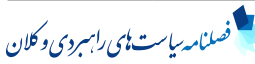

در جدول شماره سا ، رابطه تمامى عامل ها با متغير مكنون تأييد شد (سطح معنادارى مربوط به كليه سؤالات

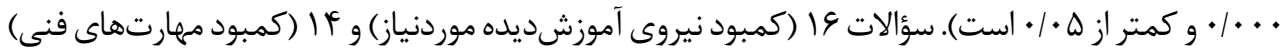

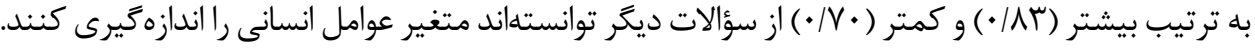

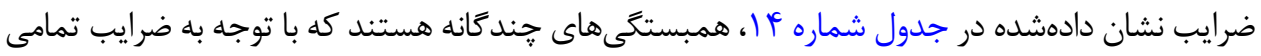

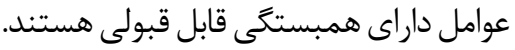
ب-0. تحليل عاملي ثأنيبي مثغير عوامل مالب

با توجه به نسبت كاىاسكوئر مدل عوامل سازمانى به درجه آزادى، شاخصهاى برازش تطبيقى، شاخص

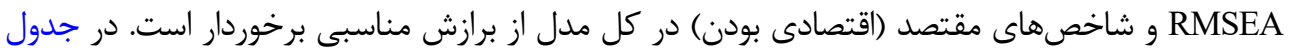

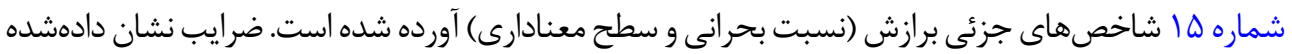

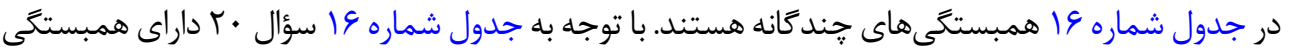


جدول ال. مربع ضريب همبستكى هاى خندكانه

\begin{tabular}{|c|c|}
\hline Estimate & كويهها \\
\hline .1990 & q16 \\
\hline - IOAF & q15 \\
\hline - / FAO & q14 \\
\hline
\end{tabular}

| th

جدول ها. شاخص هاى برازش مدل

\begin{tabular}{|c|c|c|c|c|c|c|c|c|c|c|c|}
\hline $\mathbf{P}$ & PCFI & PNFI & PRATIO & GFI & RFI & IFI & CFI & NFI & RMSEA & $\chi^{2} / d f$ & شاخصها \\
\hline$>+1.0$ & $>+10$ & $>+10$ & $>+10$ & $>. / 9$ & $>. / 9$ & $>. / 9$ & $>. / 9$ & $>+19$ & $<+1+\Delta$ & $<Y$ & بهترين ميزان \\
\hline . & "זr &.$/ M T$ & H &.$/ 99$ &.$/ 97$ &.$/ 99$ &.$/ 99$ &.$/ 41$ & $.1 \cdot 14$ & $y \cdot r$ & محاسبهشده \\
\hline
\end{tabular}

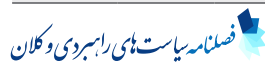

جدول 19. مريع ضريب همبستيكى هاي جند هانه

\begin{tabular}{|c|c|}
\hline Estimate & كويهها \\
\hline.$/ p 4 p$ & $q 22$ \\
\hline.$/ m W$ & q21 \\
\hline.$/ 194$ & $q 20$ \\
\hline.$/ m t$ & q19 \\
\hline
\end{tabular}

24

جدول VIV آماره تي و سطح معثادارى

\begin{tabular}{|c|c|c|c|c|c|c|c|}
\hline ضريثب & معiاد|رى & بحرانى(أماره & استثاندالرد & غيراسثاندارد & $\begin{array}{c}\text { (عوامل) } \\
\text { (عاداد }\end{array}$ & كويdها & \\
\hline$+|8| \varepsilon$ & & & & 1 & مالى & (كمبود منابع مالى) & q19 \\
\hline$\cdot|\Delta V|$ & & & & 1 & مالىى & (هزينهالهاى نصبي، & q21 \\
\hline .1899 & $\ldots+1$ & $\Delta / 8+q$ & $\cdot \pi+\Delta$ & V/IPV & مالى & (هنازينه بالا متخصصان & $q 22$ \\
\hline
\end{tabular}

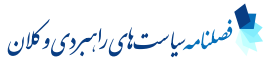


جدول 11. مربع ضريب همبستكّى هاى جندكُانه

\begin{tabular}{|c|c|}
\hline Estimate & كويلها \\
\hline.$/ 719$ & $q 22$ \\
\hline.$/ M Y E$ & q21 \\
\hline.$/ r v q$ & q19 \\
\hline
\end{tabular}

| th

ضعيفى است و بايد از مدل حذف و آزمون مجدد انجام شود. در جدول شماره V V ، ر ابطه تمامى عاملها با متغير مكنون تأييد شد (سطح معنادارى مربوط به كليه سؤالات

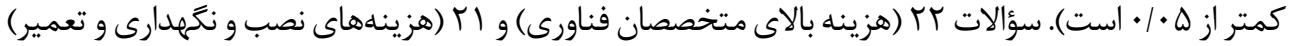

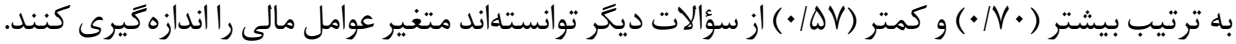
ضرايب نشان دادشده در جدول شماره 11 همبستخى هاى جند إنانه هستند كه با توجه به ضرايب تمامى

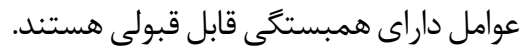

\section{ب-7 تحليل عاملي ثأييدى متغير عوامل محيطي}

با توجه به نسبت كاىاسكوئر مدل عوامل سازمانى به درجه آزادى، شاخصهاى برازش تطبيقى، شاخص RMSEA شماره 9 شاخصهاى جزئى برازش (نسبت بحرانى و سطح معنادارى) آورده شده است است در جدول شماره • r، رابطه تمامى عامل ها با متغير مكنون تأييد شده است (سطح معنادارى مربوط به كليه

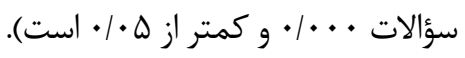

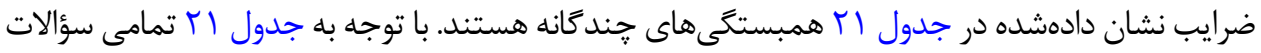

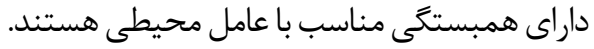

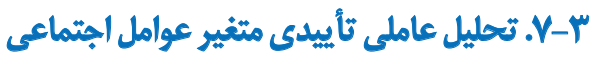

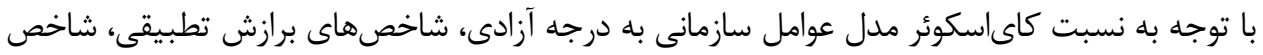
RMSEA

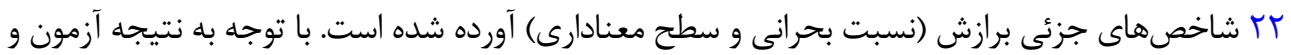

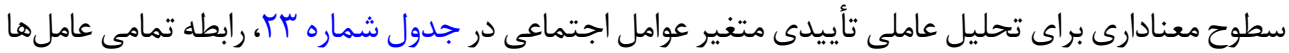

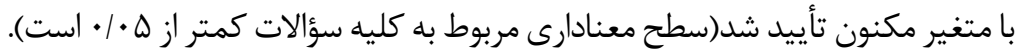




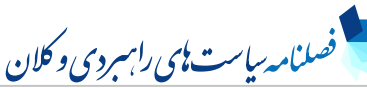

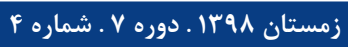

جدول 19. شاخصهاى برازش مدل

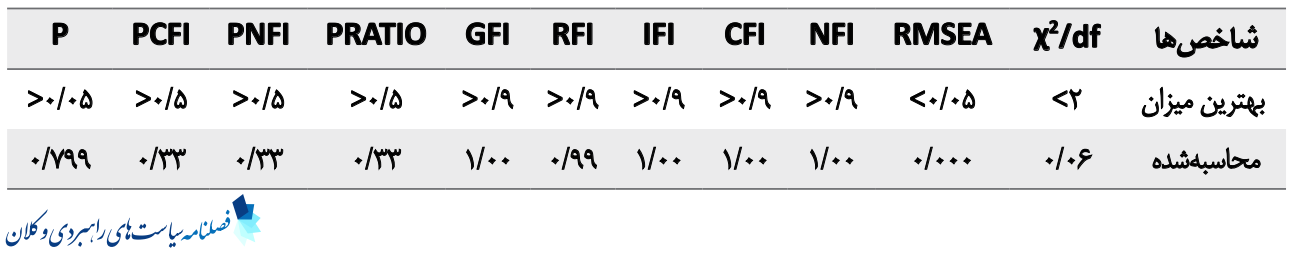

جدول •T. آماره تي و سطح معنادارى

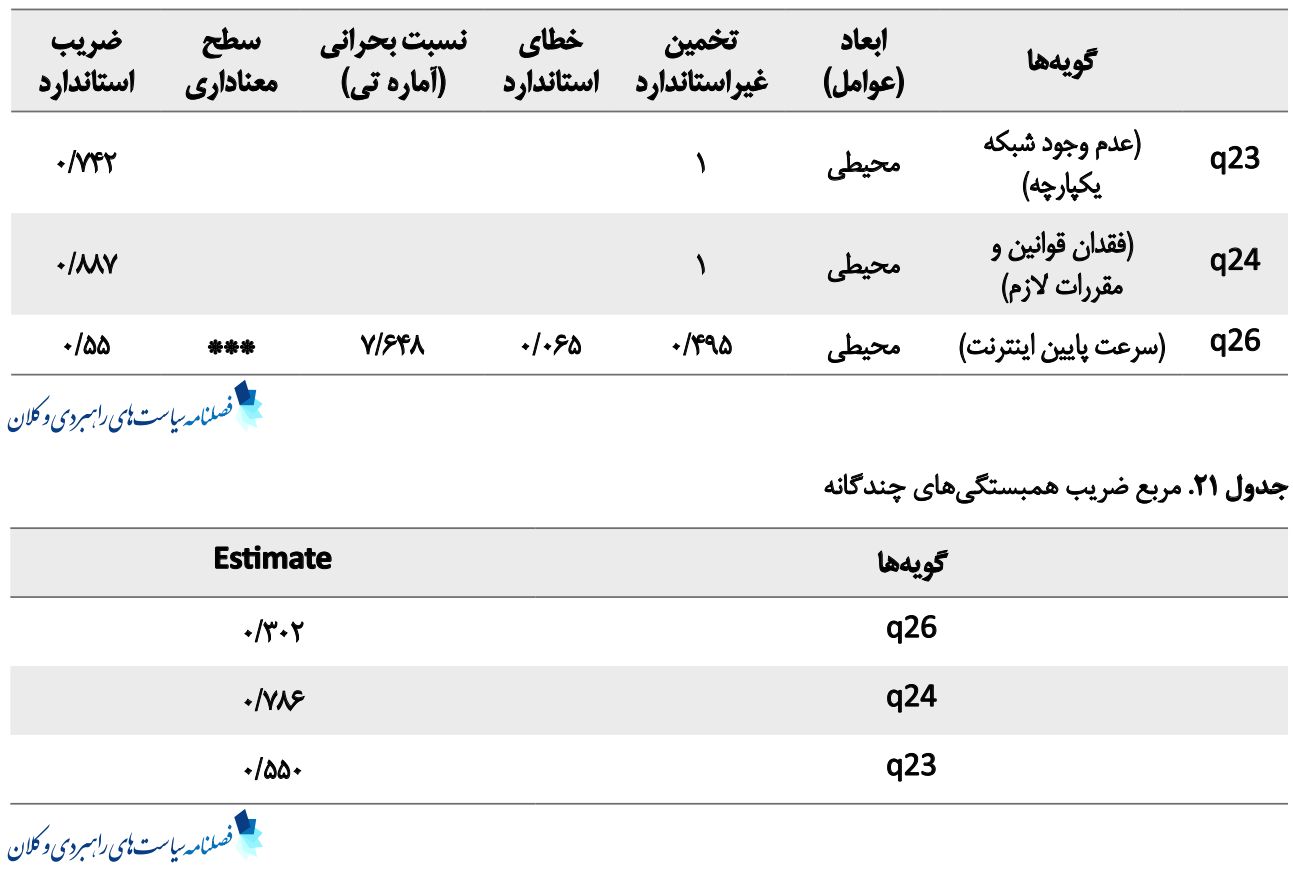

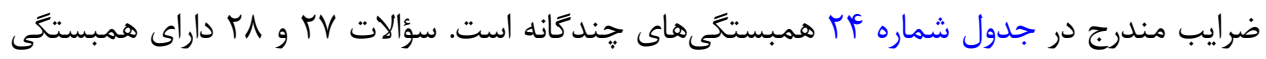

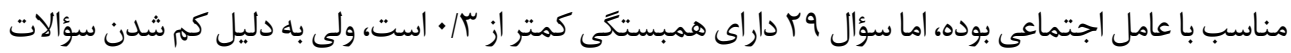

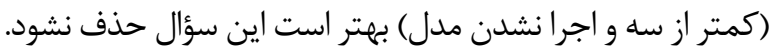

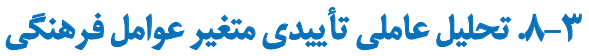

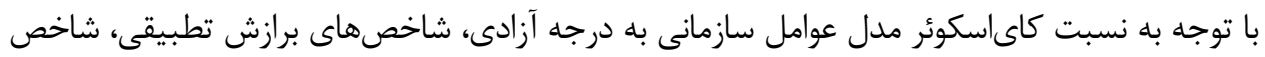
RMSEA

عيسى جمشيدى و همكاران. بررسى موانع استقرار ماده شباتون مديريت خدمات كشورى در سازمانهاي دولتي

G. T 
جدول rr. شاخصهاى برازش مدل

\begin{tabular}{|c|c|c|c|c|c|c|c|c|c|c|c|}
\hline $\mathbf{P}$ & PCFI & PNFI & PRATIO & GFI & RFI & IFI & CFI & NFI & RMSEA & $\chi^{2} / d f$ & شاحِص ها \\
\hline$>\cdot 1 \cdot 0$ & $>\cdot 10$ & $>\cdot / \Delta$ & $>\cdot 10$ & $>. / 9$ & $>. / 9$ & $>. / 9$ & $>+19$ & $>. / 9$ & $<\cdot 1 \cdot \Delta$ & $<r$ & بهترين ميزان \\
\hline$+\pi$ & זr/. & זM/. & זד/. &.$/ 99$ &.$/ 9 \Delta$ &.$/ 99$ &.$/ 99$ &.$/ 4$ & $.1 \cdot \Delta$ & Vaf & محاسبهشلد \\
\hline
\end{tabular}

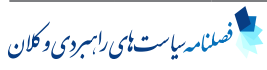

جدول ب.T. آماره تي و سطح معنادارى

\begin{tabular}{|c|c|c|c|c|c|c|c|}
\hline ضريب & معادار & نسبت بحرانى & استاندارئ & غَيراستَائدارد & 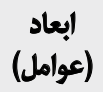 & Lيdئ & \\
\hline.$M T Y$ & & & & 1 & الجتماعى & (فقدان اطلاعرسانى) & q27 \\
\hline . $/ 19$ & & & & 1 & الجتماعى & (علاقه كاركنان به الكترونيك) & $q 28$ \\
\hline.$/ 899$ & $\%$ & d/qIf &.$M I V$ & - 1897 & اجتماعى & 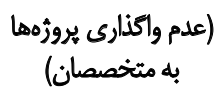 & q29 \\
\hline
\end{tabular}

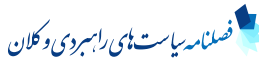

جدول IF. مربع ضريب همبستكى هاى جندكانه

\begin{tabular}{|c|c|}
\hline Estimate & كويهها \\
\hline.$/ \pi p q$ & q29 \\
\hline.$/ 01 \mathrm{~V}$ & $q 28$ \\
\hline - larq & q27 \\
\hline
\end{tabular}

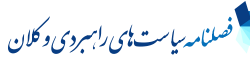

جدول Ta. شاخص هاى برازٌش مدل

P PCFI PNFI PRATIO GFI RFI IFI CFI NFI RMSEA $x^{2} / d f$ هاخص هان

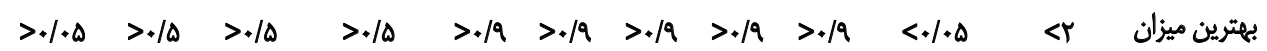
محاسبdial (2) 
جدول \&ץ. آماره تى و سطح معنادارى

\begin{tabular}{|c|c|c|c|c|c|c|c|}
\hline ضريبان استبارد & معنادارى & نسبت بحرانيى & استاندارد & غيراستاندارد & (عوامل) & 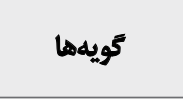 & \\
\hline.$/ \Delta V t$ & & & & 1 & فرهنكى & صحبود آموزش) & q30 \\
\hline .199 &. & g/Trq & $\cdot \pi M$ & $1 / \% q$ & فرهنئى & دولت الكترونيك) & q31 \\
\hline - IEVi & 10. & $8 / 19$ &.$/ M I E$ & I/rTs & فرهنكي & (مقاومت در برابر & $q 32$ \\
\hline - Iapt & $+\ldots$ & 91.80 & $\cdot R+r$ & I/TKE & فرهنكى & تمكنز زياد روىى) & q33 \\
\hline
\end{tabular}

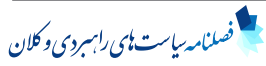

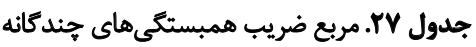

\begin{tabular}{cc}
\hline Estimate & Lهods \\
\hline$/ / F i f$ & $\mathrm{q} 33$ \\
.$/ F \Delta \Delta$ & $\mathrm{q} 32$ \\
.$/ F v e$ & $\mathrm{q} 31$ \\
.$/ \mathrm{Fq}$ & $\mathrm{q} 30$ \\
\hline
\end{tabular}

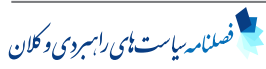

ها شاخصهاى جزئى برازش (نسبت بحرانى و سطح معنادارى) آورده شده است در جدول شماره צr، رابطه تمامى عاملها با متغير مكنون تأييد شد(سطح معنادارى مربوط به كليه سؤالات

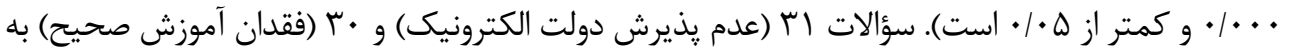

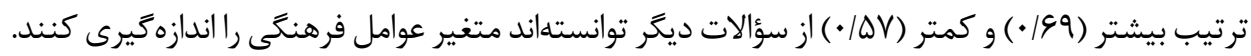

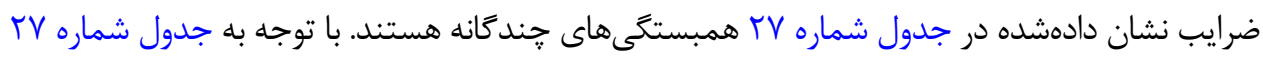

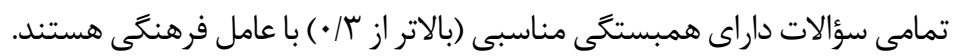

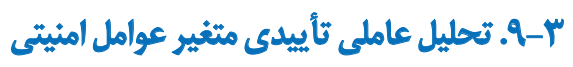
با توجه به نسبت كاىاسكوئر مدل عوامل سازمانى به درجه آزادى، شاخصهاى برازش تطبيقى، شاخص 


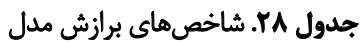

\begin{tabular}{|c|c|c|c|c|c|c|c|c|c|c|c|}
\hline $\mathbf{P}$ & PCFI & PNFI & PRATIO & GFI & RFI & IFI & CFI & NFI & RMSEA & $x^{2} / d f$ & شاحمصها \\
\hline$>+1 \cdot \Delta$ & $>+10$ & $>\cdot / \Delta$ & $>+10$ & $>. / 9$ & $>. / 9$ & $>. / 9$ & $>+19$ & $>. / 9$ & $<+/ \cdot \Delta$ & $<r$ & بهترين ميزان \\
\hline.$/ p q$ &.$/ 18$ & .118 &.$/ 18$ &.$/ 99$ &.$/ 41$ & $1 /$. & $1 /$. &.$/ 99$ &.$\ldots$ &.$/ F \Delta$ & محاسبهشهد \\
\hline
\end{tabular}

جدول T. مريع ضريب همبستكي هاي جند مانه

\begin{tabular}{|c|c|}
\hline Estimate & تويهها \\
\hline . /rAT & q37 \\
\hline.$/ M r F$ & q36 \\
\hline - IFAY & q35 \\
\hline ./rrr & q34 \\
\hline
\end{tabular}

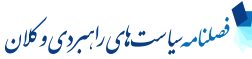

و شاخصهاى مقتصد (اقتصادى بودن) در كل مدل از برازش مناسبى برخوردارند.

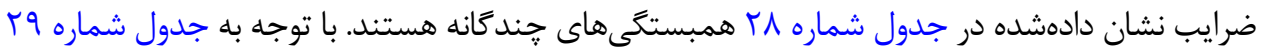

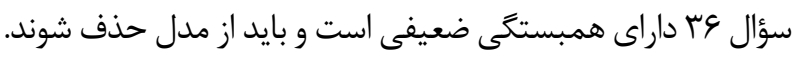
در جدول شماره • ب، رابطه تمامى عاملها با متغير مكنون تأييد شد (سطح معنادارى مربوط به كليه سؤالات

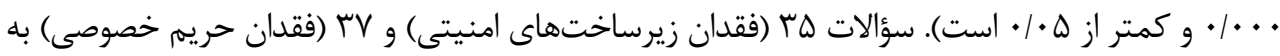

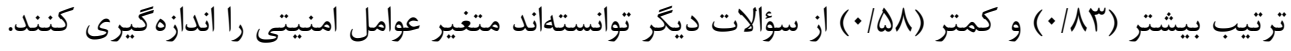

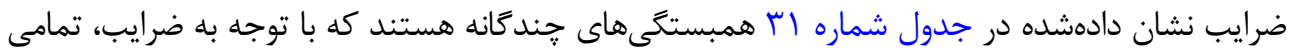

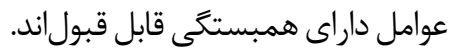

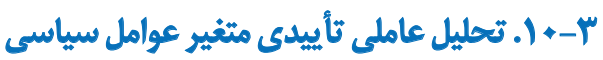

با توجه به نسبت كاىاسكوئر مدل عوامل سازمانى به درجه آزادى، شاخصهاى برازش تطبيقى، شاخص

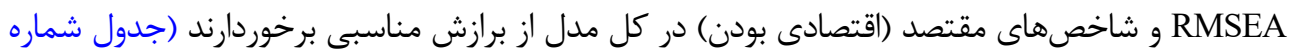

در جدول شماره سبا، رابطه تمامى عاملها با متغير مكنون تأييد شد (سطح معنادارى مربوط به كليه سؤالات

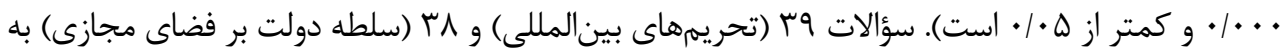


جدول +r. آماره تى و سطح معنادارى

\begin{tabular}{|c|c|c|c|c|c|c|c|}
\hline ضريب & معنادارى سطع & نسبث بحرانيى & استانداري & غيراستمين & (عوامل) & كويه & \\
\hline.$/ \Delta A Y$ & & & & 1 & المنيتي & (ققدان امنيت سيسثمها) & q34 \\
\hline - /Arq & .1. & $\Delta / M E$ & . RAE & $V / \Delta \cdot \Delta$ & امنيتى & (فقلان زيرساختهاي & q35 \\
\hline$+/ \Delta V A$ & & & & 1 & المنيتى & (فقدان حريم خصوصى) & q37 \\
\hline
\end{tabular}

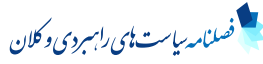

جدول آ. مربع ضريب همبستكىهاى جند مانه

\begin{tabular}{|c|c|}
\hline Estimate & كويهها \\
\hline . Imf & q37 \\
\hline - lear & q35 \\
\hline.$/ M F$ & q34 \\
\hline
\end{tabular}

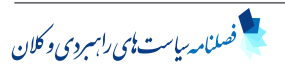

جدول rا. شاخص هاي برازش مدل

\begin{tabular}{|c|c|c|c|c|c|c|c|c|c|c|c|}
\hline $\mathbf{P}$ & PCFI & PNFI & PRATIO & GFI & RFI & IFI & CFI & NFI & RMSEA & $x^{2} / d f$ & شاخصها \\
\hline$>.1 \cdot \Delta$ & $>\cdot 10$ & $>\cdot 10$ & $>\cdot 10$ & $>.19$ & $>.19$ & $>.19$ & $>. / 9$ & $>.19$ & $<\cdot 1 \cdot \Delta$ & $<r$ & بهترين ميزان \\
\hline$\cdot / M$ &.$/ M$ & 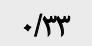 &.$/ \pi n$ & $1 /$. & .199 & $1 /$. & $1 / \cdots$ & .199 & $1 \ldots$ & .111 & هدالسبهأشده \\
\hline
\end{tabular}

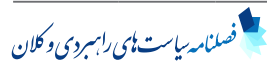

جدول بr. آماره ثنى و سطح معنادارى

\begin{tabular}{|c|c|c|c|c|c|c|c|}
\hline ضريبا & منادارى & نسبث بتراتئ & استاندارئ & غيراستائدارد & 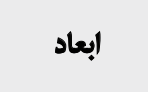 & كويلها & \\
\hline$\cdot / \Delta$ & & & & 1 & عوامل سياسى & (سلطه دولت بر فضاى & q38 \\
\hline . /ArA & .1. & $\Delta / r$ & . Mif & I/EeV & عوامل سياسي & 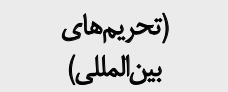 & q39 \\
\hline.$/ 814$ & & & & 1 & عوامل سياسي & (كميود و ابهام قواثين) & $\mathrm{q40}$ \\
\hline
\end{tabular}

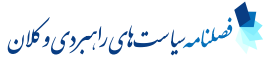




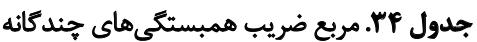

\begin{tabular}{|c|c|}
\hline Estimate & كويهها \\
\hline.$/ m V^{e}$ & $q 40$ \\
\hline.$N \cdot r$ & q39 \\
\hline . KA & q38 \\
\hline
\end{tabular}

(1)

جدول هاr. شاخصهاى برازش مدل

\begin{tabular}{|c|c|c|c|c|c|c|c|c|c|c|c|}
\hline $\mathbf{P}$ & PCFI & PNFI & PRATIO & GFI & RFI & IFI & CFI & NFI & RMSEA & $\chi^{2} / \mathrm{df}$ & شاخص ها) \\
\hline$>\cdot 1 \cdot \Delta$ & $>+10$ & $>\cdot / \Delta$ & $>+10$ & $>. / 9$ & $>. / 9$ & $>. / 9$ & $>. / 9$ & $>. / 9$ & $<\star / \bullet \Delta$ & $<r$ & بهترين ميزان \\
\hline$\cdot /{ }_{1}$ &.$/ A 1$ & .10 & $. / \Delta \mid$ & ./9V &.$/ q$ &.$/ 99$ &.$/ 99$ &.$/ 4$ & 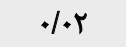 & VIr & هحاسبه شده \\
\hline
\end{tabular}

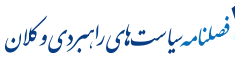

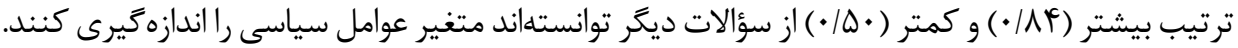

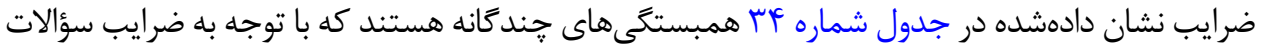

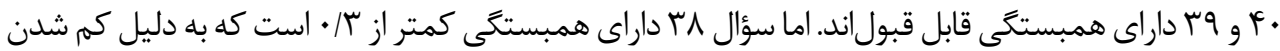

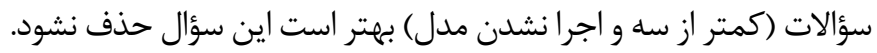

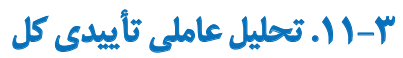

با توجه به نسبت كاىاسكوئر مدل عوامل سازمانى به درجه آزادى، شاخصهاى برازش تطبيقى، شاخص ماري RMSEA هـ شاخصهاى جزئى برازش (نسبت بحرانى و سطح معنادارى) آورده شده است.

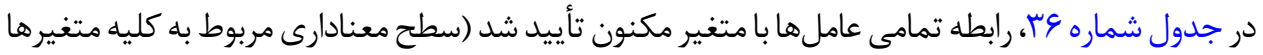

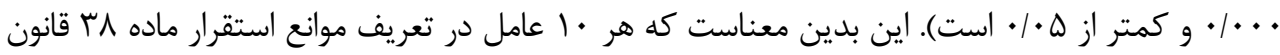

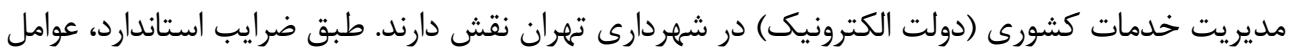

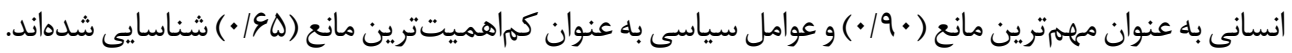

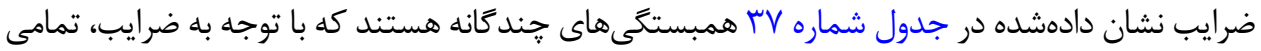

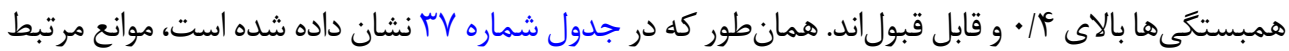

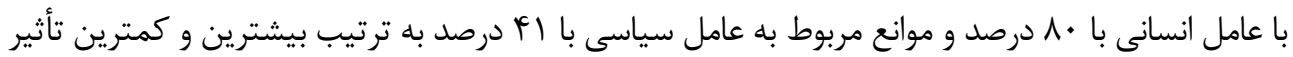


جدول وץ. آماره تى و سطح معنادارى

\begin{tabular}{|c|c|c|c|c|c|c|}
\hline ضريب & معنادارى سطح & نسبت بحرانيى & استاندارد & غيراستاندارد & & ابعاد \\
\hline.$(A) \mathrm{V}$ & & & & 1 & موانع & عوامل مديريتى \\
\hline.$M 19$ & $1 \%$ & IF/MT & .1 .09 & - MEA & موانع & عوامل سازمانى \\
\hline$\cdot N \cdot 8$ & $+1+$. & $\mid r / a \cdot 1$ & .1 .09 & - Ner & موانع & عوامل فنى \\
\hline ./1997 & $1 \%$ & $\mid f / \lambda \cdot f$ & .1 .81 & $.19 \cdot 9$ & موانع & عوامل انسانى \\
\hline$\cdot M r a$ & $.1 \%$ & IT/MTY & $.1 .8 r$ & - Nar & هوانع & عوامل مالى \\
\hline$\cdot|V A|$ & 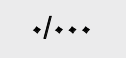 & Ir/aTV & $\cdot / \cdot \Delta r$ & $.18 M$ & هوانع & عوامل محيطى \\
\hline$\cdot / V \Delta \Delta$ & .10 & $1 r / r 19$ & $.1 .9 V$ & - AMY & موانع & عوامل اجتماعى \\
\hline$\cdot M r V$ & $+\ldots$ & $11 / \mathrm{HgV}$ & .1 .94 & - MIr & مواتع & عوامل فرهنكى \\
\hline.$M I 8$ & .10 & 1.NAF & $.1 .8 V$ &.$M I A$ & هواثع & عورامل امنيتي \\
\hline .180 & .10 & $q / \Delta F^{\prime}$ & $\cdot 1 \cdot n$ & .1810 & هواثع & عوامل سياسى \\
\hline
\end{tabular}

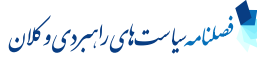

در استقرار دولت الكترونيك را دارند. نتيجه كلى آزمونها نشاندهنده تأييد تمامى متغيرهاى مستقل (عوامل

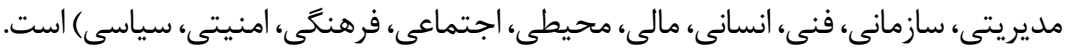

\section{ى}

استقرار كامل دولت الكترونيك مزاياى بالقوهاى دارد با توجه به مطالب ارائهشده و نتايج اين يزوهش، تمامى

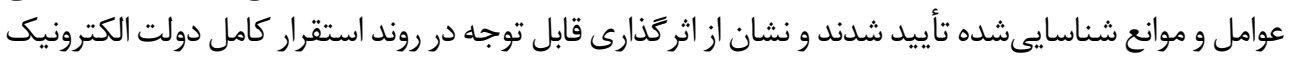

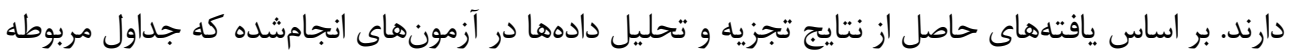

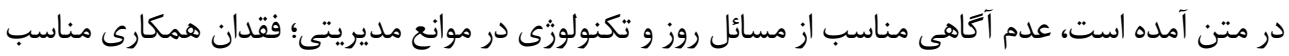

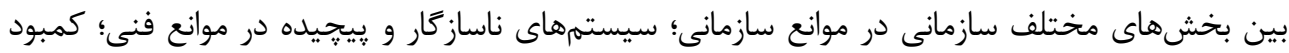

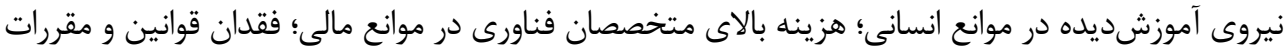

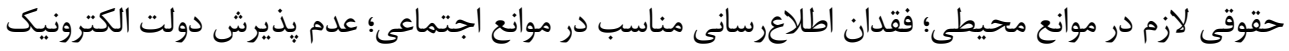

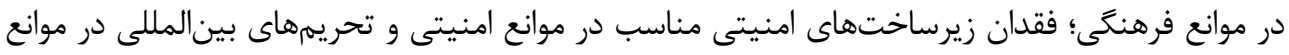

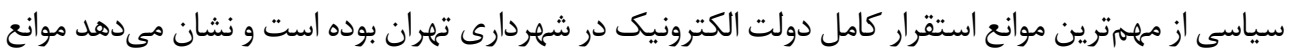

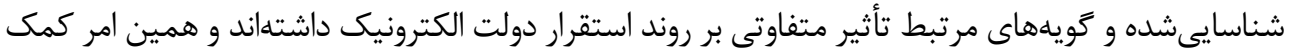

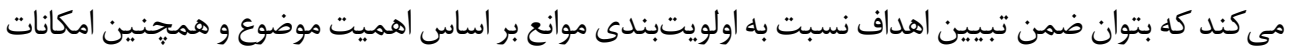
موجود اقدام كرد. 
جدول TV. مربع ضريب همبستكى هاى جندكانه

\begin{tabular}{|c|c|}
\hline Estimate & متغير مستقل \\
\hline - /FrT & عوامل سياسي \\
\hline.$/ D I Y$ & عوامل امنيتي \\
\hline - IAPr & عوامل فرهنكى \\
\hline - IAPQ & عوامل اجتماعى \\
\hline .181 & عوامل محيطى \\
\hline .18 .8 & عوامل مالى \\
\hline$+\mid A+F$ & عوامل انسانى \\
\hline.$/ F q$ & عوامل فنى \\
\hline ./DIV & عوامل سازمانى \\
\hline .1881 & عوامل مديريتى \\
\hline
\end{tabular}

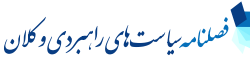

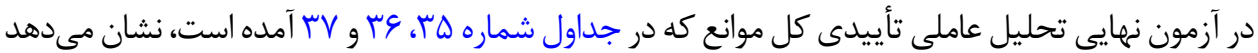

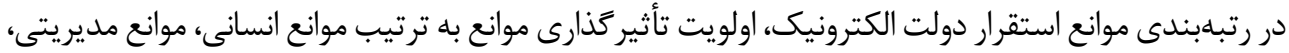

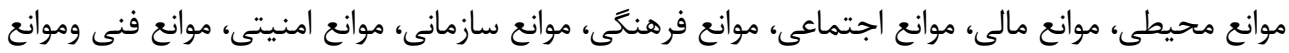

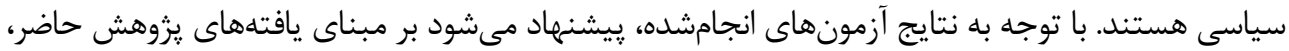

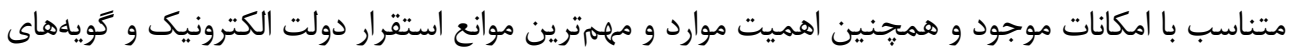

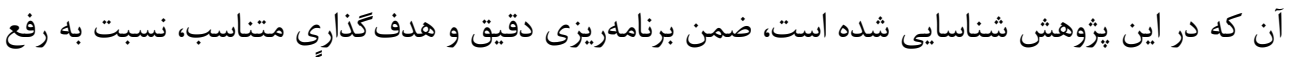

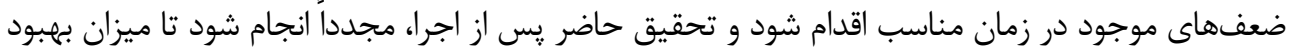

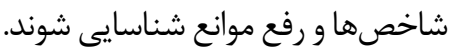

\section{ملاحظاث اخلاقى}

\section{بيروى از الصول اخلاق بروهش}

همه اصول اخلاقى در اين مقاله رعايت شده است. شركت كنند

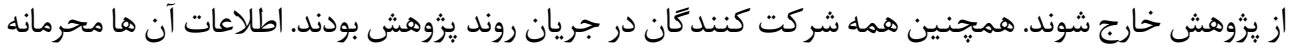




$$
\text { مامي مالى }
$$

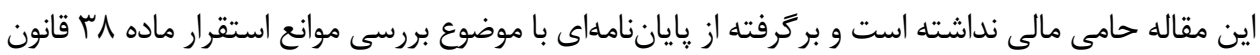

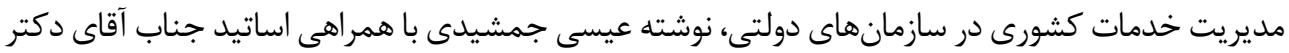

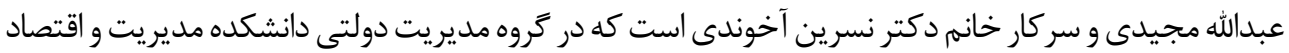

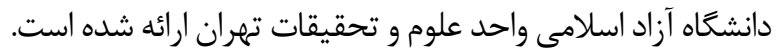

$$
\text { هُشاركت نويسندمَان }
$$

تمامى نويسندًان به يك اندازه در نغارش اثر مشاركت داشتداند.

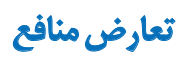

بنابر اظهار نويسندگان اين مقاله تعارض منافع ندارد. 


\section{References}

Amiri, A. N., \& Hasaninejad, A. (2012). [Implementation of E-government implementation - looking at the situation of E-government in Iran (Persian)]. Rahbord, (8), 81-98. https://www.noormags.ir/view/en/articlepage/914646

Ebrahim, Z., \& Irani, Z. (2005). E-government adoption: Architecture and barriers. Business Process Management Journal, 11(5), 589-611. https://www.researchgate.net/publication/235254120

Entezari, M. H. (2014). [E-government rating (Persian)]. Paper presented at $7^{\text {th }}$ Conference of Electronic Administrative System, Amirkabir University of Technology, Tehran, Iran, 12-14 August 2014.

Faghihi, M. (2014). [E-government rating (Persian)]. Retrieved from Not Found Link

Ghasemi, V. (2010). [Structural equation modeling in social research using Amos Graphics (Persian)]. Tehran: Sociologists Publications. http://opac.nlai.ir/opac-prod/bibliographic/1899609

Ghorbani, A., Sarafrazi, M., Hemati, F., \& Ebrahimi, M. (2006). [E-government and its implementation methodology (Persian)]. Paper presented at the $2^{\text {nd }}$ International Conference on Information and Communication Technology Management, Tehran, Iran, 20-21 February 2006. https://www.civilica.com/Paper-ICTM02-ICTM02_023.html

Hill, F., \& Hezlett, S. (2003). E-goverment the realities of using it to teransform the public sector. Managing Service Quality: An International Journal, 13(6), 445-52. [DOI: org/10.1108/09604520310506504]

Jalali, A. A. (2011). [Electronic city (Persian)]. Paper presented at $2^{\text {nd }}$ Conference on Electronic City, Tehran, Iran, 24 May 2009.

Jalali, A. A. (2003). [Electronic city (Persian)]. 1 $^{\text {st }}$ Ed. Tehran: Iran University of Science and Technology. http://opac.nlai.ir/opac$\mathrm{prod} /$ bibliographic/707677

Rezaei, H. R., \& Davari, A. (2004). [Electronic government (Persian)]. Tadbir, (146), 17-22. https://www.magiran.com/volume $/ 8338$

Sarfarazi, M., \& Memarzadeh, G. R., Ghorbani, A. (2008). [Paradigm of E-governmant an essential necessity in establishment E-municipality (Persian)]. Paper presented at the $4^{\text {th }}$ International Conference on Information and Communication Technology Management, Tehran, Iran, 18-19 February 2008. https://www.civilica.com/Paper-ICTM04-ICTM04_045.html

Yaghobi, N. M. (2009). [Electronic government: Management approach (Persian)]. Tehran: Afkar. http://opac.nlai.ir/opac-prod/ bibliographic/973522 